New horizons of chemistry of the XXI century

E.Z. Golosman

Ltd. «NIAP-Katalizator», 10, Svjazi St., Novomoskovsk, 301660, Russia E-mail:evgolosman@yandex.ru; golosman.niap@mail.ru

\title{
Engineering and scientific elite at the Mendeleev congress in Ekaterinburg and reflections about science and education
}

The article by professor Eugene Golosman was dedicated to Mendeleev congresses, science, education, officials, conferences, Hirsch index, Academies of Russian Academy of Sciences, RIA, MANEB, competitions «Engineer of the Year», the Mendeleev Museum, the catalysts, the Union of scientific and engineering organizations, chemical society named D. I. Mendeleev. Eugene Zinov'evich is acting in the press, on television, radio and as a great scientist, and as a famous public figure. The raised issues are of a sharp polemic character, but always they seen the sincere interest of the author in addressing of key issues.

The evidence of the importance of the problems under consideration are the numerous responses from readers, responses from the heads of Committees on science, education, the State Duma, the number of Departments of the Ministries of the Russian Federation, the Russian Academy of Sciences and its departments.

Key words: Mendeleev Congress; higher education; production workers; D. I. Mendeleev; the Academy of Sciences.

Received: 09.01.2017; accepted: 25.02.2017; published: 14.04.2017.

Новые горизонты химии XXI века

Е.3. Голосман

ООО «НИАП-Катализатор»

Россия, 301660, Новомосковск, ул. Связи, 10 E-mail:evgolosman@yandex.ru; golosman.niap@mail.ru

\section{Инженерная и научная элита на Менделеевском съезде в Екатеринбурге и размышления о науке и образовании}

Статья профессора Евгения Голосмана посвящена Менделеевским съездам, науке, образованию, чиновникам, конференциям, индексу Хирша, Академиям РАН, РИА, МАНЭБ, конкурсам «Инженер Года» музею Менделеева, катализа- 
торам, Союзу научных и инженерных организаций, химическому обществу им. Д. И. Менделеева.

Евгений Зиновьевич выступает в прессе, по телевидению, радио и, как крупный ученый, и как известный общественный деятель. Поднимаемые вопросы носят острый полемический характер, но всегда в них видна искренняя заинтересованность автора в решении важнейших вопросов.

Свидетельством важности рассматриваемых проблем являются многочисленные отклики читателей, ответы руководства Комитетов по науке, образованию, ГосДумы, ряда департаментов Министерств РФ, Российской Академии Наук и ее отделений.

Ключевые слова: Менделеевский съезд; вузовское образование; производственники; Д. И. Менделеев; Академия наук.

Поступило: 09.01.2017; принято: 25.02.2017; опубликовано: 14.04.2017.

(c) Golosman E. Z., 2017

Recently in the capital of the Urals Ekaterinburg the XX Mendeleev Congress on General and applied chemistry was hosted. The Report-back election Congress of the Mendeleev chemical society was held in one of these work days of the Congress.

Plenipotentiary representative of the President in the Urals Federal district Igor Kholmanskikh voiced a greeting of Russian President Vladimir Putin to the Congress. Sverdlovsk Governor Yevgeny Kuyvashev addressed the Congress. The head of the Federal Agency of scientific organizations Mikhail Kotyukov congratulated the Congress on behalf of the Chairman of the RF Government D. A. Medvedev.

Vice-President of RAS academician Sergei Aldoshin expressed confidence that the Congress will allow to identify the main ways of industry development in the next five years.

The Chairman of the Ural branch of the RAS academician Valery Charushin at the Congress and at the opening of the exhibition recalled the motto of the breeders Demidov - «deeds, not words».

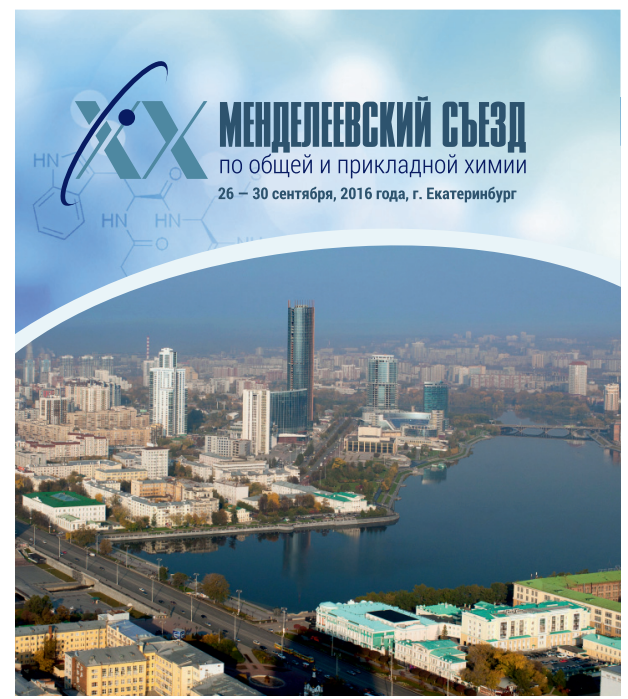

The President of the International Union of pure and applied chemistry (IUPAC), corresponding member of RAS Natalia Tarasova welcomed the Congress.

The permanent President of many programs of the Mendeleev congresses academician Oleg Nefedov and Chairman of the Russian Foundation for Basic Research, academician Vladimir Panchenko welcomed the Congress on video.

The President of the Russian chemical society, academician Aslan Tsivadze recalled 
that recently the Russian cities other than Moscow and St. Petersburg were not ready to receive thousands of Congress.

The capital of the Urals managed to organize such Grand public gathering.

The organizers of the Congress were the Russian Academy of Sciences, Ural branch of Russian Academy of Sciences, Federal Agency of scientific organizations, the Government of Sverdlovsk region, the
Russian Chemical Society named D. I. Mendeleyev, Ministry of Education and Science of the Russian Federation, Ural Federal University named the First President of Russia B. N. Yeltsin, the national Committee of Russian chemists, Russian chemists Union. The Congress was held under the auspices of the International Union of pure and applied chemistry (IUPAC).

\section{The First Mendeleev Congress}

The first Mendeleev Congress to the memory of D. I. Mendeleev "Questions of General chemistry, chemical industries, technologies and applications of chemistry in different branches of science and technology» was held in St. Petersburg in 1907. The Congress was attended by representatives of 80 cities. Later the congresses were held in Moscow, Leningrad (Saint-Petersburg), Kazan, Kharkov, Kiev, Alma-ATA, Baku, Tashkent, Minsk, Volgograd.

The theme of the Congresses covers the key directions of development of chemical science, technology and industry, chemical education and interaction of business with science and industry, which distinguishes them from common scientific conferences. The Mendeleev congresses are organized every four to five years in the largest scientific centers of the country and determined the path of development of chemical science and industry of Russia.

About 2000 delegates, including 300 foreign scientists and representatives of companies involved in the production of chemical products and materials participated in the largest Russian scientific forum in Ekaterinburg.

There are Nobel laureates, more than 100 academicians and corresponding members of Russian Academy of Sciences, hundreds of professors and doctors of Sciences,

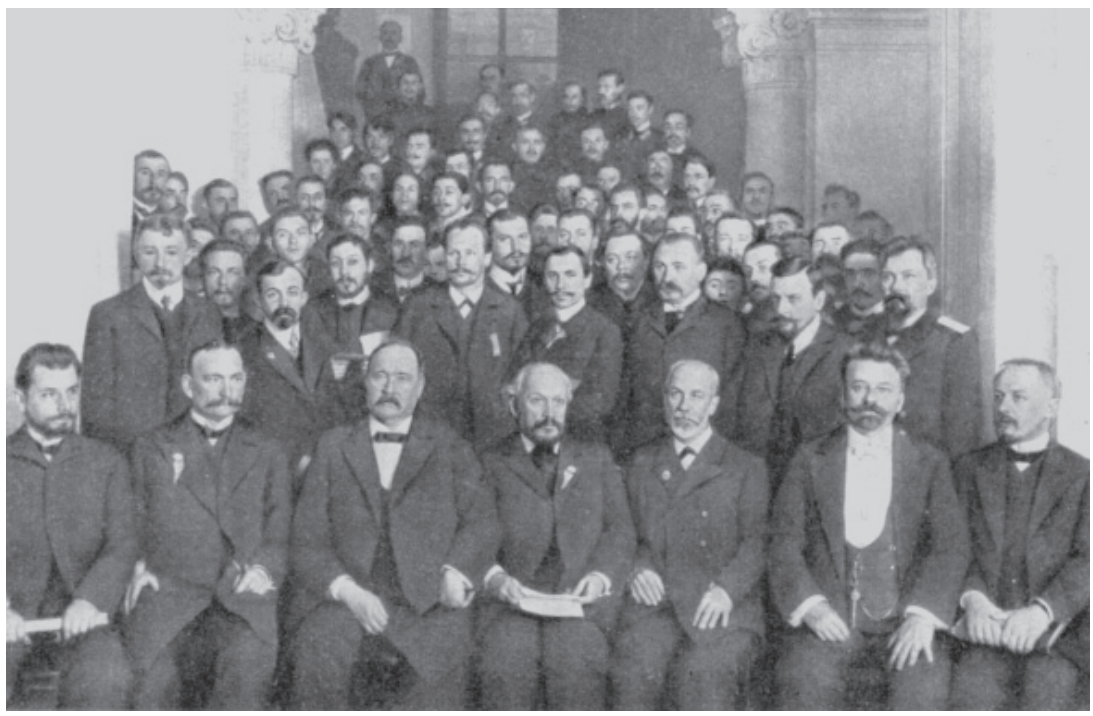


700 young scientists among 2000 participants of the XX Congress. The President of the Russian Engineering Academy, corresponding member of Russian Academy of Sciences, laureate of the Government prize of the Russian Federation B. V. Gusev and other active members of this Academy; academician, laureate of the State prize and the prize «Energy» V. N. Parmon, academician of RAS, Honored Petrochemist of the USSR, laureate of Government Prize of the Russian Federation S. N. Hadzhiev; the Government prize laureate the academician V. V. Lunin, academician, laureate of the State prize M.P. Egorov and others also took part in the Congress. More than 1,100 scientists made oral and poster presentations. About 2,500 abstracts on behalf of the 7800 authors in Russian and English were published in 5 volumes of materials of the Congress.

The discussion of many chemical problems, including chemical education and teaching in Russia, the interaction between chemical science and business, actual problems of the nitrogen industry, in addition to plenary, oral and poster presentations were held in the framework of the $9 \mathrm{sec}-$ tions, 3 International symposia, 10 round tables, which represented a great platform for discussions of the experts of science and industry, defining the direction and development of the metallurgical, petrochemical and other industries.

Of course, the implementation of such large public gathering would be difficult without the financial contribution of sponsors and dozens of organizations.

The leadership and members of the organizing Committee, Moscow and the Ural experts, scientists of the Ekaterinburg and, of course, hundreds of young volunteers (students and postgraduates) in beautiful $\mathrm{t}$-shirts with the inscription «I love chemicals» were of great assistance in the conduct of the Congress. With gratitude I must mention a tremendous job of scientific secretaries of the Congress, Dr. of chemical Sciences, Professor Yu. G. Gorbunova, candidate of chemical Sciences O. A. Kuznetsova.

Ekaterinburg is the largest centre of chemical and metallurgical industry of Russia, the capital of the Urals was chosen to host the XX Congress

\section{The Congress in the Tauride}

Of course, to read, to listen to stories, watch on television is very interesting but, of course, nothing can replace personal participation in congresses.

I was lucky enough in life to participate in several of the Mendeleev congresses in Leningrad, Minsk, Moscow, Volgograd... The participation in the X Mendeleev Congress in Leningrad in 1969 was most memorable, which was dedicated to the 100th anniversary of the opening of Dmitri Ivanovich Mendeleev periodic table. As they say, with open mouth I watched the famous organizers and participants of the Congress, held in the Tauride Palace in Len-

ingrad. 2,000 people including many foreign guests took part in the X Congress. I call a few names: Nobel laureate N.N. Semenov,

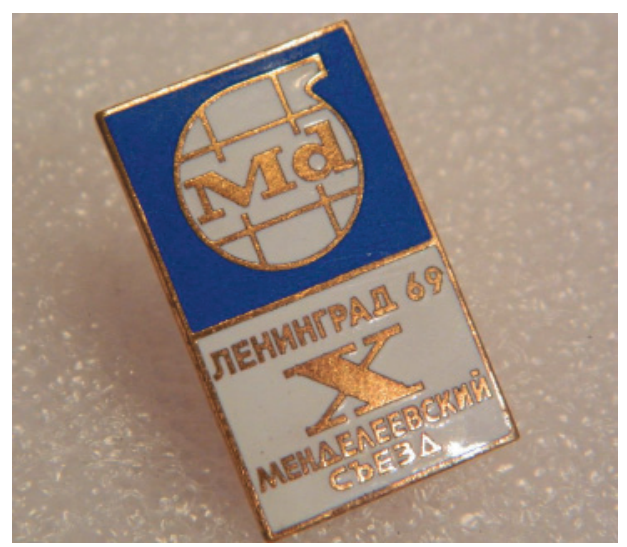


academicians S. I., Volfkovich, N. M. Lark, Gol'danskii, V. I. Tananaev, Y. K. Syrkin, Deputy Chairman of the Council of Ministers, V. A. Kirillin, Minister of education V.P. Elyutin and dozens of the most famous scientists in the world. What presentations were made by the discoverers of new elements - the legend of science, academician G. N. Flerov (opened 104 element - rutherfordium, and in honor of the Flerov element 114 is named flerovium), Chairman of the atomic energy Commission USA G. Seaborg (synthesized plutonium, and together with other scientists discovered americium, curium, berkelium, californium, einsteinium, fermium, mendelevium, in 1997 in honor of Seaborg the 106th element is named ceaborgium). And the reports of the Minister of chemical industry L. A. Kostandov, Director of the Institute of catalysis academician G. K. Boreskov were impressive.

\section{King Henry IV}

Unwinding of tape memory, I thought and the possibility of the participants of the Congress to visit theatre of Arkady Raikin and first heard and seen by me scenes of then still not very well known in the country, the brilliant Mikhail Zhvanetsky performed by Raikin. Unfortunately, ordinary members of the Congress did not have the opportunity to purchase tickets to the Bolshoi Drama theatre under the direction of famous producer George Tovstonogov. I having been to the beginning of the theatrical play to the theater and talking with the manager, who explained to me that the tickets here are the local currency, I realized the hopelessness of getting into the theatrical hall. It was light rain, I walked along the Fontanka river, where the theatre was and I thought, how I can get to theatrical play. And finally the desperate idea came to my head, which is characteristic only of reckless youth. I'm waiting for the intermission, take off my nylon coat, put it in the gutter and together with the audience, released during the intermission outside to smoke, I go to one of the lodges and watch standing two acts of the play «King Henry IV» by William Shakespeare with great actors Sergey Yursky, Oleg Borisov, Evgenie Lebedev, Yefim Kopelyan, Vladislav Strizhelchik, Oleg Basilashvili, Nikolai Trofimov, etc.

And after dozen years I think that I was then a young specialist, the employee of branch of the State Institute of nitrogen industry and was lucky to take part in the Congress, and how much it gave me in further work and I hope, in the transfer of the commitment to science to my young colleagues in the created sector, laboratory which bore the name of SCAR (study of catalysts, adsorbents, reactions). I think that I did something for science, industry. There are hundreds of articles, books, reports, patents, developed catalysts are introduced at nearly 200 enterprises of the USSR, Russia, CIS and far abroad. But, apparently, SCAR and many industry and academic research institutes flew very closely to the sun and now it's not, unfortunately.

\section{Periodic legality}

But back to Ekaterinburg. On behalf of my colleagues - experts «NIAP-Katalizator», NAK «Azot», «Nizhnekamskneftekhim» I submitted two reports to Congress (on cat-

alysts of methanation and purification of propane) and at the round table «Actual problems of nitrogen industry» (under the leadership of corresponding member the 
RAS V. G. Sister) a report about the industrial catalysts, developed and produced in the «NIAP-Katalizator».

Dozens of sections and round tables scattered in the giant center EkaterinburgEXPO, thousands of reports to listen, of course, was impossible, despite a very tough program (the beginning of the Congress at $9 \mathrm{am}$ and ending at $20 \mathrm{pm}$ ). I mention some from the most prestigious reports.

Many years ago D. I. Mendeleev said: «Periodic legitimacy for the first time gave the chance to see else undiscovered elements so far, which chemical vision unaided by this legality until then not achieved and thus new elements informed of their discovery draw a lot of properties». These predictions soon came true brilliantly. In our days the discovery of new elements continues. This is evidenced from the report of Yu. Ts. Oganesyan and S. N. Dmitriev about the discovery of new superheavy elements with atomic numbers 113-118 of periodic table of D. I. Mendeleev. The opening of a new region of stability of superheavy elements has created a whole range of new questions and, in particular, where the boundaries of the periodic table of D. I. Mendeleev. Academician Yuri Oganesyan together with two American scientists have been nominated for the Nobel prize in chemistry in 2016, but the prize was received by other scientists. Recently the question was resolved finally and one of the newly discovered elements will now bear the name of Oganesyan. Also the question was resolved on naming one of the new elements - Moscovium (in honor of the Moscow region Dubna), where is the joint Institute for nuclear research, jointly with Lawrence Livermore national laboratory (USA) conducted experiments for the discovery of new elements). However, as noted by academician Oganesyan «In our

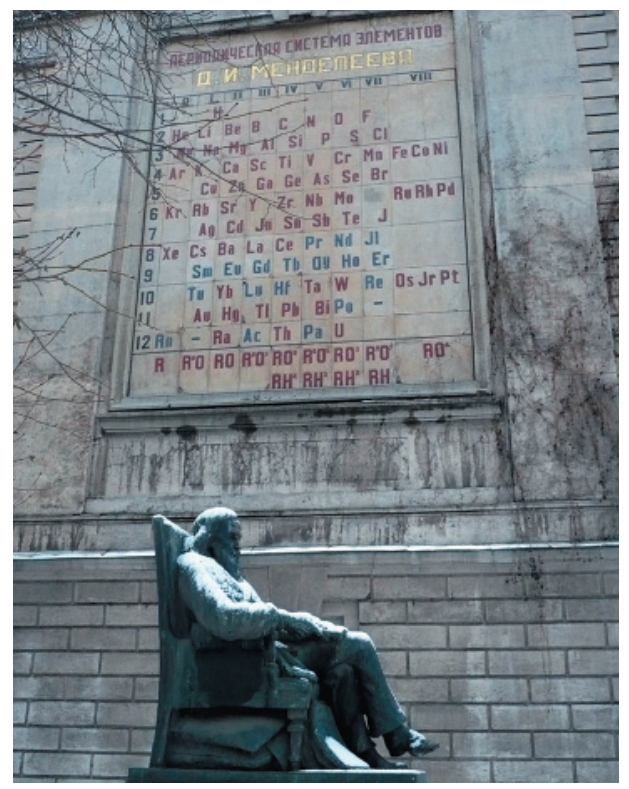

country one opens and the other has the right to name».

At the closest to me for many years the subject (catalysts) reports of academician V.I. Bukhtiyarov, professor V. M. Kapustin, academician A. G. Dedov, corresponding member of RAS Z. R. Ismagilov made the greatest impression. I mention only a few of the reports (of the many) who failed to listen to personally.

For the Russian and world science, the importance of the Congress was underlined by the participation of the President of the RAS academician V.E. Fortov with report "Chemical elements in extreme conditions». A speech in the message V.E. Fortov was about the behavior of chemical elements in conditions of ultrahigh pressures. At the same time their properties change dramatically. In the coming years, there is perhaps the discovery of the chemical elements that do not fit into the periodic table, which undoubtedly will force to expand the boundaries of knowledge.

Of course, there is the brilliant report by Nobel laureate Daniel Shehtman, professor at the «TECHNION» (Haifa, Israel) and the 
University of Iowa (USA). No revolution in the science of crystalline materials was not expected. to the works of D. Shehtman. For more than 10 years his works would not even print, criticized. But he persistently argued the importance of his scientific ideas. In the end, the Nobel Committee noted that its discoveries have forced the scientific world to reconsider their views about the nature of the materials. There is a great example of devotion to science and perseverance in achieving goals.

\section{Where there are production workers...}

I would like to point out the problems with the audience of our speakers. The time requirement is the implementation of developments, and number of production workers (engineering managers, heads of departments, leading and chief engineers) is extremely small. The reason is the miscommunication of owners and management companies, insufficient awareness of plants and the exorbitant cost of almost all scientific conferences, conducted at least for the last 15-20 years. Unlikely due to the current production employment, as well as high cost the employees, even from the surrounding regions from the location of the conference could not participate in scientific forums for $4-5$ days. But it really would be to organize the delivery of engineering and technical personnel alternately for a day at least. It is necessary also send invitations to our conferences not only to directors and chief engineers, but it is necessary to inform personally and their deputies, chiefs of industries, shops, etc. I remember that in Nizhnekamsk the chief engineer of OJSC «Nizhnekamskneftekhim» has led to the conference «Innovative petrochemical technologies» about ten directors of the plants. And each of them

\section{And again about education}

Of course, a lot of questions were related to university and high-school education. Science, education, medicine can not, should not be services. I will focus on the problem of the closure is briefly told what problems they have in production. The workers outlined the objectives and asked the scientists to solve these problems. Otherwise, as happens now, researchers talk to other researchers about their achievements that it is imperative to implement. New achievements of the Russian developers do not reach producers, and most importantly are not discussed with the practices. Hence, perhaps, there are the illusions of developers from universities and academic research institutes which do not represent fully (in contrast to specialists of branch institutes) the most difficult problems with scaling their achievements.

I remember how at a conference «Scientific bases of preparation and technology of catalysts» academician I.I. Moiseev after his plenary report noted that he listened to a huge number of messages with beautiful modern methods, excellent appliances, and new industrial catalysts are enough!

Our Congress is also no exception, and it is devoted to fundamental and applied chemistry. Here are also largely unclaimed potential of Russian science, though of course there are many other reasons. They are slightly lower.

of a number of universities. This is especially painful for the regions. Yes, it is possible to strengthen a few dozen universities in Moscow, St.-Petersburg, Novosibirsk and other scientific centers. Of course, 
who would argue -good institutions with modern equipment devices and qualified teachers are need. Yes, it would be good, if they were all at the level of the Massachusetts, California,... the Indian institutes of technology, or our Physical technical Institute. But it's unreal. But only 15-20\% of adolescents will be able to arrive for study in these universities, the parents of other adolescents will not be able to provide financially. Besides, most universities have a lack of places in hostels. Did the authors of the idea of reducing of the number of universities to minimum think about that how much graduates from these universities go back to work in the province after the temptations of life in the capital and other cities?

According to the information of the President of the Russian Academy of Sciences and the Chairman of the Committee on science of State Duma, nearly $80 \%$ of the graduates of metropolitan universities who came to study from different cities, are staying in megalopolises. Who will work in factories, design departments, research institutes, the Russian open spaces?

To strengthening of provincial universities it's need to send there mostly young candidates and doctors of Sciences from leading universities and research institutes of the country (of course, with their consent and with the provision in the first phase of service apartments with the right of privatization in 7-10 years), as it was done once many years ago.

Of course, it's need to "refresh the blood», to establish links of various scientific schools, and not to carry out mechanical reduction of students and teachers, and not to deprive the regions capabilities of education and culture centers. It would not had to recall the old joke: to the question, which institute is easiest to get, followed by the answer - in the institute of Sklifosovsky.

In Novomoskovsk in 1958 the branch of the Moscow Institute of Chemical Technology (now the SR RUCT) was organized. More recently, the number of full-time, part-time Russian and foreign students was approximately 5000. There are the huge buildings, the stadium, dormitories. Our giants - NAK «Nitrogen», «Procter \& gamble», «Plaster of Knauf», TPP, «NIAP-Katalizator», etc. enterprises of Novomoskovsk, Tula, Efremov, Schekino were provided by the graduates (technologists, mechanics, power engineers, economists) for many years. The graduates of SR RUCT named D. I. Mendeleev work in dozens of Russian cities.

Whose wisest decisions led to a sharp reduction in students, teachers? The city of chemists, engineers and the region will be left without University... I thought about who was nominated, endorsed, appointed Ministers A. Serdyukov, D. V. Livanov, the acts which in the field of science, education, the army will long disentangle country?

Who is the concrete author of the law about the so-called reform of the Russian Academy of Sciences? The diligent, zealous conductors of this reform are enough, but still would love to know the main authors.

It is time to solve questions of graduation of the bachelors (unfinished engineers).

Who will be working on high-tech enterprises? It should be noted that the demand for bachelors in the industry is virtually nonexistent. It seems that the country back in the thirties of the last century, when it was necessary to prepare the technical specialists in a hurry on the workers 'school. It is known that even engineers have to complete their education in enterprises for the purpose of production of the industry. The good full-fledged en- 
gineers are need. And instead of bachelors it is necessary to increase the training of qualified technicians and lab technicians in technical schools and colleges. It's necessary, at least at universities, if a shortage of students is experiencing, students can, in my opinion, to prepare as technicians and laboratory assistants. Thus, the download of the lecturers of these universities and use, as a rule, richer than in technical schools and colleges training base will be provided.

If the state needs more highly skilled workers, there are still technical schools, colleges, professional schools. If they are insufficient and need in the 21st century, more skilled workers, let's release them further in technical universities. The society will get highly skilled workers. Will remain The good base on the basis of universities will remain, and the teaching staff will be protected. I remind that in developed countries the share of highly skilled workers is up to $50 \%$, and in Russia - 5-10\%.

It is necessary to save the technical universities, especially those located in industrial regions, but to strengthen their material base and teaching staff with involving, as noted above, experts from leading research institutes and factories. The students of these universities will undertake training in the surrounding businesses and, of course, they will first be able to replenish the corps of engineers in their regions. Is it not clear that graduates of MSU, LSU, NSU... designed primarily to work in the Russian Academy of Sciences, analytical centers and can't resolve problems with engineering personnel.

The issue of attracting of professors and associate professors employed in research institutes and industrial enterprises to universities has long been discussed. It is the symbiosis of university teachers with assistants initiated once the legendary Moscow Engineering Physical-Technical Institute, demonstrated a high efficiency in the preparation of undergraduate and graduate students.

The Department of catalysis of Novosibirsk University, headed by academician of RAS, Director IR, SB RAS Vladimir Bukhtiyarov shows excellent results in the training of undergraduate and graduate students. A significant proportion of teachers are the employees of the IR of the SB RAS, where, in addition, the students and graduate students can work at real problems and listen to lectures of leading specialists and later to work at the famous Institute of catalysis.

Unfortunately, in some universities the picture is quite different. By following out decree of the President of Russia about increasing of salaries of university employees, there is washing away part-time workers reported to be $0.1-0.5$ wage rate, thus, raising his average salary to high school teachers. Who is it for camouflage? Who are we kidding? We deprive students and graduate students of contacts with leading practical specialists. And, above all, who will prepare engineers from students without specialists of research institutes and factories?

At the presidential Council on science and education it discussed about the loss of popularity of engineering education, the shortage of qualified engineers, which become the constraining factor of the development of the economy, and about the need to bring education to the production, about that educators have to teach students who know modern production that real university is university where there is science and that not only university educators but also practitioners should be taught students, for which the Ministry of Education will eliminate excessive barriers like restrictions 
on moonlighting, for those who are doing science or working on a real production.

\section{And we're dreaming Hirsch}

And once again about rating of scientists, engineers, about citation and Hirsch index. How can you compare scientists, teachers, engineers and to do assessment of their work on different publications. One author wrote a review article that is cited many times. Another author wrote an article on the new results, which may be quoted in a few years. How to compare time for preparation of one large article and 2-3 small articles. What if some materials at certain stages, can be quite long, are closed and the authors have no possibility of publication. In addition, the citation depends on the number of researchers in this field.
Changes not yet visible. What are else need directions?
Hirsch index is an important but not the only defining assessment of the level of researcher. I repeat multiple statements made in the scientific community. Hirsch index cannot serve as an absolute, objective criterion for the evaluation of the activities of the scientist. It reflects the overall result of the work, but not efficiency

We jump aside all the time: a Single state exam, Hirsch, consolidation and liquidation of universities, the Bologna system. I'm not talking about «cross-pollination» - mutual agreement of citing of articles between the parties. And finally, the highest rating is achieved when printing in foreign magazines for publication some of which require payment requires.

\section{Ab ovo (lat. from egg)}

At the Congress, round tables, on the sidelines, of course, the questions of reorganization of RAS were discussed. Three years have passed. Have any results achieved? In my opinion, except expenses (insoluble contradictions between RAS and FANO), this reform did not improve anything..

Of course, there are a lot of questions to the work of RAS, but who doesn't? Who does not remember about the problems not only in RAS but also branch research institutes, let's see the numbers of drop in GDP, as well as monthly, annual reports of the investigative Committee and other power structures about the different agencies, including well-known public persons. Yes, it is necessary to clean the ranks of the scientific community, first and foremost, from bare administrators. But it would be nice that the deputatskiy corps, so zeal- ously supported by unprepared law on the reorganization of the RAS, also cleaned their ranks, especially after the speech of leader of the Liberal Democratic Party, who said that in the Academy there are all the old, and that after 40 years the brain for creativity runs out. Or does the brain need only to scientists?

For 300 years Russia has developed academic science. Why is need to break it through a knee? If the train station works badly, it is not demolished and the chief exchanges.

At one meeting the President of Agricultural Academy of Sciences Gennady Romanenko said that «at all times our leaders think about science when in the country there are problems, and when with the help of science they are eliminated, they begin to reform the science». 
What kind of understanding of destructive process of elimination and even - the new wording is supposedly a reorganization can be discussed when during the debates about the law on RAS in the State Duma, candidate of economic sciences, Deputy Prime Minister Olga Golodets said that after the reforms the sectoral science is alive and well, and Academy after the reforms will live well. And this is declaration to the deputies, all over the country and including all of us, the staff of defeated branch research institutes.

Many years ago, when they began to destroy the institutes, I interviewed a number of academicians and leading scientists of the RAS, proved that if you do not stop the rout of branch research institutes, Academy of Sciences, with its huge property in the center of usually the largest cities will be next. Academics did not joined to the ranks of the defenders. Although they resented, but quietly. Remember at Saltykov-Shchedrin: «the Governors are on their knees, but it is clear that rebelling»? What is it, in particular, brought? To implement the development has become problematic. The Academy is increasingly criticized by the fact that its researches are divorced from industry although the funding is modest. The intention of mainly selective funding of individual groups is totally unacceptable, which of course will lead to petty themes. Even the best scientists and laboratories invariably need to replenishment of the scientific masses. To determine administratively what research groups must cease financing is the very dangerous and will lead to a mass resignation of researchers. The effects of this impact catastrophically in a short time. This is evidenced by the Russian and international experience. In Russia there is no longer excess of scientists, and we are on the number of researchers per 10,000 people somewhere in the third ten.

The reform of such complex Corporation of scientists like RAS slow down the development of Russian science for many years. Academician, Nobelevskiy winner I. Pavlov about the first reforms of the young Soviet power in the 20 -ies of the last century, ironically commented: «I would try first on the dogs».

The Confirmation of rashness of reforms is the continuing departure abroad of talented engineers and other specialists. I repeat the classic example. Germany, who lost after the war, plants, equipment, leading scientists and designers after the war have been unable to reclaim, for example, superiority in aircraft even decades later.

The losses of Russia only from the departure of our talents abroad from the inventor of television V. Zworykin and chemist V. Ipatiev to the Nobel laureates K. Novoselov, A. Geim is ten times higher than the annual budget of the Russian economy.

Along with the leak of young, energetic minds abroad, and possible patents leaked. The cost of obtaining patents is very high. If patents don't give, there is high probability of intercept of the developments by foreign companies. What, don't need the fixing of inventions of Russia to the state? The number of accepted patents of the Russian Federation in the year is inferior to the USA more than 15 times, and China more than 40 times.

We know from human history that basic research will sooner or later ends up applied results (laser and thousands of other examples). Yes, science is a risky industry. It takes about three thousand ideas to get one large real commercial product. But even in this case firms and the government get huge profit. It is necessary to know everything, including the poorly prepared critics of science. 


\section{The drivers and officials...}

The acceptance of officials to RAS raises many questions and complaints in society. What attracts them there? Of course, I suppose that is the prestige, the creation of alternate aerodromes and the opportunity to practice good positions, well, lifelong scholarship of academicians and corresponding member of RAS will not be superfluous.

And yet, I think that there prestige, ambition in the first place. It was in tsarist times, the Soviet Union and continues today. It concerns and the desire of thousands of officials of all ranks, especially in the field of law, political science, sociology, history to become candidates and doctors of Sciences

Very interesting story is about the desire of one of the king's war Ministers to become an academician. Academics were gathered, they don't know what to do. How does he relate to science, what are scientific papers? One of the leaders of Imperial Academy says that he's still close to the king. What free-thinking academician noticed that the driver of the Royal carriage is closer to the king and even sitting with my back to him... the Minister has not elected, and the academician was sent.

The separate theme is nepotism, the «roofs» at the Academy. For a long time on my Skype hangs «Has the science the "bullying"?» There are still some! But this theme requires a separate page and a separate discussion. «The moral of the story is: Another label is stronger than a lion».

\section{The effectiveness of scientific research}

Yet, despite all problems, we can cite many examples of the effectiveness of scientific researches for «citizen» and «defense». I focus on few close to me examples of topics related to the development of effective catalysts underlying in basis of the 85-90\% of all chemical technologies, used in various industries. The total volume of world production produced in a year by using catalytic technologies, is estimated at $\$ 3$ trillion dollars. The cost of the annual production used for this catalyst does not exceed
13-15 billion dollars. In other words, the fraction of the cost of catalysts in the output producible with their help usually does not exceed fractions of a percent. This is the effective research developments! It is pleasant to note that among the 500 industrial catalysts used in chemicals, petrochemicals, metallurgy and other industries of the Russian economy more than four decades is the development of my hometown of Novomoskovsk Institute of nitrogen industry («NIAP-Katalizator»).

\section{Catalyst is the strategic concept}

Despite the fact that the production of catalysts in Russia for a long time attributed to the so-called critical technologies, the share of imported catalysts supplied in our country is steadily growing and accounts for a variety of industries from $60 \%$ (nitrogen industry) to $90 \%$ (getting gasoline). I remind you that a large part of chemical and petrochemical products is manufactured using catalysts. The catalysts are used in all

industries for purification of technological and exhaust gases. The exporting countries, if it's necessary, can exert the enormous pressure by restricting the supply of necessary catalysts. The consequence of such rigid policy is very alarming, because now the number of countries which have full complex of technologies of production of catalysts of oil refining (industries are strategic to the economy of many states), was 
less than the number of states possessing the technology of production of the atomic bomb.

I discussed the problems of sanctions with a number of managerial staff of chemical plant and reproached them that they don't help us - industry institutions, in the end, the chemical plants can remain without catalysts. The response of some professionals was discouraging. Nothing, we buy in China. As they say, thanks to the chinese proletariat for the fact that it freed the Russian proletariat from working.

Science is increasingly offered to do all yourself: and costly research and selffinancing and carry out industrial applications. As it was said in $\mathrm{KVN}$ : «What is a manicure? When it is not himself biting his nails». And yet, the words of Nobel laureate Peter Kapitsa are «the main impetus of each work is discontent».

The production of catalysts is reduced. Europe's largest catalyst plant in the city of Dorogobuzh, which was built on developments and projects GIAP and his Novomoskovsk branch completely was closed. Thousands of tons of catalysts of worldclass, including created by me with the staff were produced in the factory.

The deprivation of industry, academic, university science by necessary support with such short-sighted behavior of public figures recalls: «Girl escapes from a vampire, scratches, screams. And he speaks philosophically: "Well, why do you just piss off and nervous? I just drink a pill"».

Are there still examples of creation of new effective industrial catalysts? This is, of course, the development of the Institute of catalysis SB RAS and the latest developments of the technological Institute for superhard and novel carbon materials in Troitsk.
There are a lot of high class researchers in our country, but the list of creators of industrial catalysts, which are able to bring your product to the introduction, unfortunately is few in number. Once again I have to say -bridge of the RAS, universities, industrial science is destroyed. And yet we eat «old baggage».

I will give a few developments of our «NIAP-Katalizator» (former branch of GIAP) in the city of Novomoskovsk.

It is a catalyst for methanation processes (one of the stages of aggregates of ammonia synthesis). Its service life was able to extend from 5 years to $15-16$ years or more. The confirmed economic effect from the introduction of these catalysts was several billion rubles. Despite the expansion of foreign companies, almost all methanators in Russia and the CIS were uploaded by it.

In the last few years a new, more effective catalyst for methanation with a number of significant advantages has developed with colleagues. But there is no interest in the management of the plants when introducing a new, even a highly effective catalyst. Apparently, they think, will these heads even work? Why did they experiment...

And a very good example is the catalyst of decomposition of ozone. Ozone, when the content of it in the air already is above of thousandths of a percent, it effects on a person stronger hydrocyanic acid. We have developed jointly with the chemical Department of Moscow state University named M. V. Lomonosov and the company «TIMIS» highly efficient catalysts that operate in thousands of installations in many civil and defense industries and even in the hadron Collider in Switzerland.

In Moscow on the Western waterworks $240,000 \mathrm{~m}^{3}$ of water are ozonized (instead of chlorination) in the day and the residual ozone is decomposed in our catalysts. 
The works on the creation of catalytic decomposition of ozone are awarded by the prestigious prize of RAS named out- standing technologist of the academician V.N. Ipatiev.

\section{A new drug of plant protection}

New fungicide - copper-ammonia-carbonate solution (MAKR), having higher characteristics of protection of plants (Bordeaux mixture, copper sulphate, etc.) was created. The product does not contain harmful impurities and allows to carry out root additional fertilizing of plants, stores for a long time, in any containers and may be used for the treatment of hooves of animals and for preservation of wood products. The drug is many times cheaper than the existing ones.
There are excellent results of experimental tests in large farms and in suburban areas. But the exorbitant multi-million funding is required for the paperwork in the Ministry of agriculture and other centers. In this regard, I remember a gloomy joke:"To pull a nail out of your head you will have to pay 100 thousand rubles. But I have the same policy?! We can bend on the policy, that it not interfered".

\section{Public Academy}

And public Academies contribute to the solution of many problems of the industry, including the largest Academy - RIA, MANEB engaged in scientific and engineering activities on key issues of science and technology in almost all industries. Nobel laureate, academician Zhores Alferov, academician Aleksandr Ishlinskiy and many other academicians and corresponding member of Russian Academy of Sciences, distinguished statesmen and organizers of production, winners of foreign and the state prizes of the Russian Federation and etc. include in these academies.

The most complete and significant results of the activities were summed up at various conferences, plenums and congresses of engineers of Russia in 2003 (in the Kremlin), in 2010 and at the recently held (may 2016) in Moscow in October hall the International forum «Sustainable development and solving of scientific and technical problems in various fields of creative activity».

The preparation of RIA starts to III Congress of engineers of Russia, which will

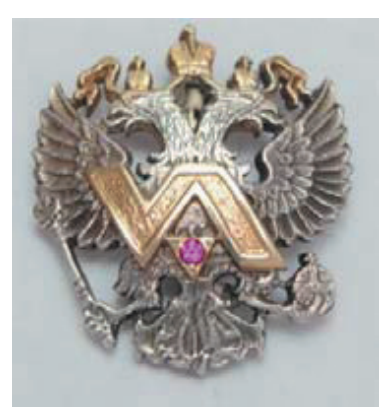

Golden Sign of RIA

probably take place in Ekaterinburg. The speeches of scientists, engineers, business leaders are shiny, the solutions are fundamental. I had euphoria especially after the first Congress in the Kremlin, and probably not only I had. There were the grand collections of the engineering elite, the smartest decisions.

What will be next in real life with science, education, critical ageing of production assets, GDP... It's not so good. All of this in our reality reminds me how our famous supervisor at all concerts before beginning got into the pocket of his coat, pulled out a note, read it and then started 
to conduct. The audiophiles could not understand, and finally, with difficulty found out contents of the not with the wife of the conductor: the violins are left, the cellos are on the right. Apparently, many of our government leaders would be nice to know where there are specialists of our countrymetallurgists, chemists, shipbuilders, electronics, power engineers, builders, geologists, engineers, economists.

\section{White nights}

I was able to visit not in many conferences and congresses held by the Academy of MANEB. I remember the 4th international conference in 1999 on ecology under the auspices of MANEB, the Ministry of Science and Technology of the Russian Federation, RAS, etc., which took place on the board of the ship «Saint-Petersburg». The was the route «Saint Petersburg - Valaam Petrozavodsk». The ship had well equipped conference hall which was almost always $100 \%$ filled by the participants.

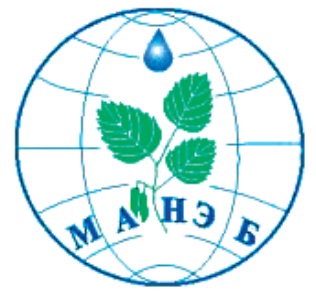

The breaks were at the time of the visit of Balaam, etc. Islands, Ladoga lake and Onega lake and Petrozavodsk. There were the beauty of the Northwest, the white nights, the historic White Sea-Baltic canal. I also had a report on the catalytic purification of process and exhaust gases.

The organizing Committee by headed President MANEB, professor Victor Rogalev recommended to speakers for preview of participants to hang their reports on the stands. My big report was well decorated and was supplied with pictures and witty sub-headings of its individual parts. The report hung in the conference room for 1.5-2 days and disappeared. The appeal of the organizing Committee with a request to return the paper was constantly on the board radio. During lunch of the participants of the conference the head of one of departments of Petersburg, who was sitting at our table heard the recurrent announcement about the missing report, invited me with a serious face not to get upset - «Your report was of use. Have you seen, Eugene Zinov'evich, that during the final approach to the island the gorgeous herring was selling, which was wrapped in your report»? The joke was a success. I did the report, but never saw the artistic text.

\section{The competition «Engineer of the year»}

The competition «Engineer of the year», which RosSNIO conducts under the guidance of academician Yuri Gulyaev and VicePresident of RosSNIO Vladimir Sitztev, become a good way to attract engineers to research and innovation activities, revealing of the elite of the engineering corps, formation of interest to engineering work of youth.
This competition in about ten years also carried out the Tula Union of scientific and engineering organizations in two versions: «Engineering art of the young» (for participants up to 30 years) and «Professional engineers». The competition had 10 categories: 1) mining and underground construction, 2) informatics, information networks, computer engineering, 3) mechanical engineering, 4) instrument making, 5) radio 
engineering, electronics, communication, 6) construction, 7) technique of military and special purpose, 8) chemistry 9) metallurgy, 10) energy.

The winners are given the diploma of the winner of the competition and the beautiful badge «Engineer of the year» made at the Mint. The awards are given annually in the Tula regional House of science and technology in the Day of Russian science, February 8 . The award ceremony is held by the administration, Council, USEA. The special issue of the newspaper is produced. The regional competition is held under the leadership of President of SNIO, professor Alexander Chukov and director of DNIIT Vladimir Mikhailovsky.

The engineers of Shchekinskii p/o «Nitrogen», the enterprises «Tulatochmash», «Tulamashzavod», Tula arms plant, plants of town Efremov, researchers, professors, associate professors, engineers of the Tula State University, SI RCTU named D.I. Mendeleev, «NIAP-Katalizator», etc. actively participate in competitions of various categories. The engineers of the defense plant «Splav» most actively participate in competitions. The general director (now scien- tific leader), the Hero of Russia, professor Nikolay Makarovets gives great support on the organization of the regional competition and the participation of the engineers of this plant in the competition for many years.

Repeatedly and engineers of the city of Novomoskovsk became the winners of the contest, and in the first place in the nomination «Chemistry» (technological, industrial, scientific and research work) and were the winners of the Russian contest «Engineer of the year» (E. Holosman, V. Efremov, A. Dul'nev, etc.). The names of the winners of the national competitions are in the hall of Fame SNIO. You can regret that a number of our chemical giants, including «NAC "Nitrogen"», «Procter \& gamble», the plaster pant for completely unexplained reasons in such prestigious competitions will not take part. Non-participation in the competition is due to a lack of understanding enterprise managers and, of course, with the lack of activity of the engineers of these companies.

And in February, 2017 the regional Union of scientific and engineering organizations celebrated the Day of Russian science. There was full auditorium (area managers, engineers of various enterprises, students

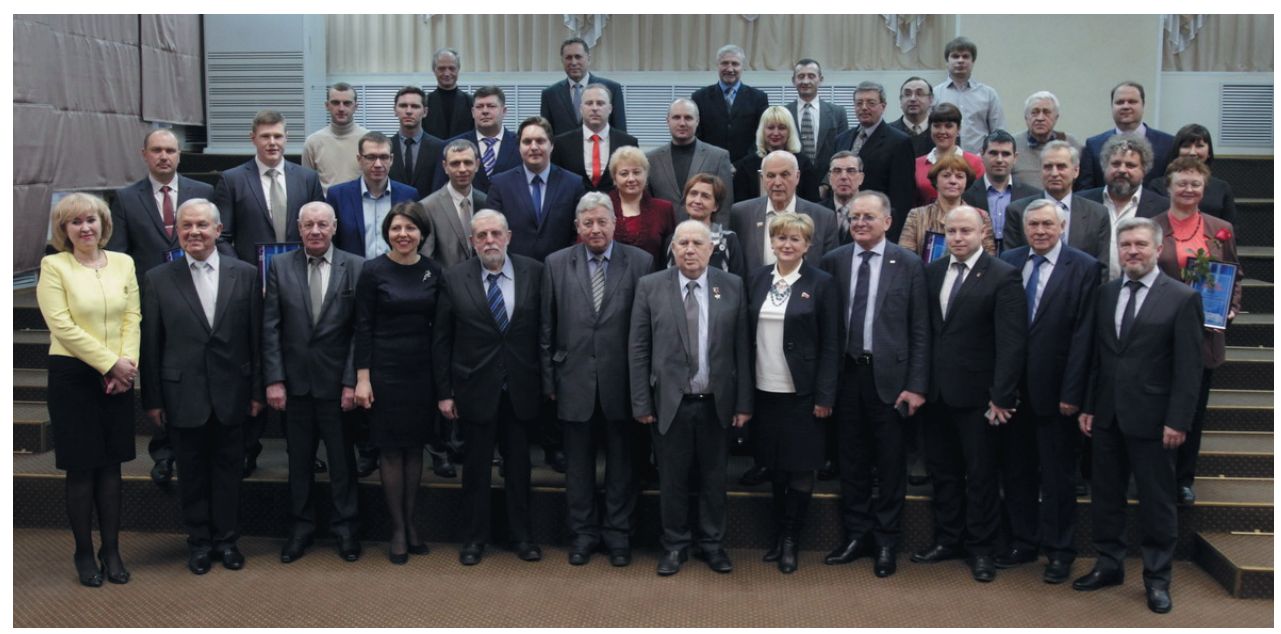

The winners of the contest "Engineer of the year" 
and University professors). In the nomination "Chemistry» six engineers from four organisations of Novomoskovsk («NIAPKatalizator», NO RKhTU named D. I. Men- deleev, «Plazmotekh» and «Piper») were the winners. All of them were awarded medals and diplomas.

\section{Handsome city}

For the participants of the XX Mendeleev Congress the cultural program was prepared. This is the sightseeing tours of Ekaterinburg, the visit to Ganina Yama (the former mine in the area which were thrown the remains of the Royal family and entourage, now there is founded the monastery)) and excursion on the border of Europe and Asia. Numerous museums, exhibitions, theatres were proposed.

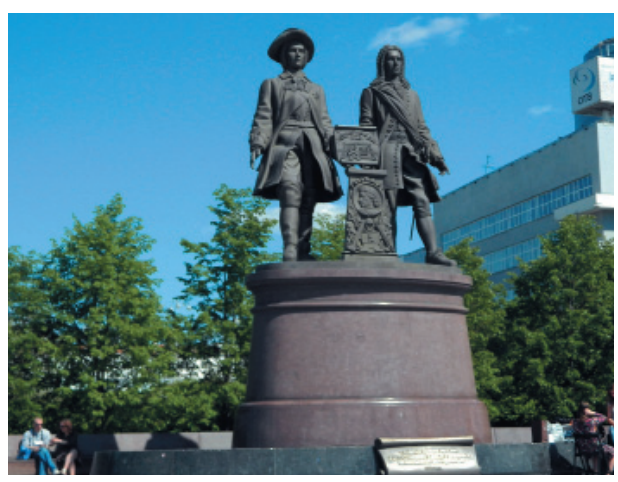

Due to the tight schedule I only managed to take the opportunity to participate in a short sightseeing tour of the city. Officially in the capital of the Urals 1.5 million people is inhabited. The high cost of land makes to build a lot of high-rise buildings (second place in Russia after Moscow). And two biggest towers «Iset» and «Vysotsky» were built. The height of the 54-storey tower «Iset» is 209 meters. The height of one of the most energy efficient buildings in the country - the 50-storey tower «Vysotsky»- is 188 meters. There is an observation deck and even a helipad. The building is a Museum of Vladimir Semenovich. This skyscraper was the first building in Russia, which was carried out vertical run. The participants overcome 1137 steps by foot.

One of the most beautiful places is the Plotinka (city pond) on the site of the former main state plant on the small river Iset. The most beautiful monument to the founders of city Vasily Tatischev and de Vilim de Gennine is next to it. The city has many of the original monuments and preserved ancient buildings.

In fact, most part of tour on the city took place through the glass of the bus. We went on «Plotinka» and near the former house of engineer Ipatiev - brother of the famous chemist-technologist of the XX century, Vladimir Nikolayevich Ipatiev (about the genius of science, the academician V.N. Ipatyev I have previously published several articles).

\section{Ipatiev house}

Many years ago I was in a long trip through the cities of the Urals (Magnitogorsk, Beloretsk, Pervouralsk, etc.) where implemented our catalysts for producing protective atmospheres in the metallurgical and pipe plants and I've been in Sverdlovsk (now Ekaterinburg). My older brother worked here. One day he went to
Pervouralsk and dropped me off at the pipe plant, where our catalyst was exploited. On the way we droved to the 2-story Ipatiev house, in the basement of which the Royal family was shoot.

The Museum of the revolution, party archive, an antireligious Museum, the exhibitions were housed in the house in 


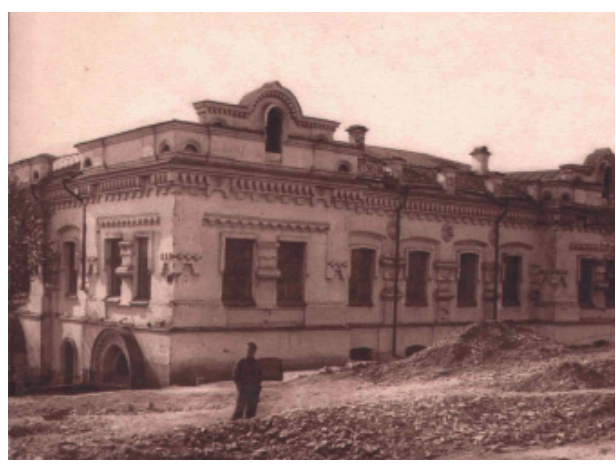

different years... In September 1977, the building was demolished. In 2003 «Church on the Blood» was built there. The height of the temple is $60 \mathrm{~m}$, its area is $3000 \mathrm{~m}^{2}$. The monument to the Tsar family is included in the ensemble of the temple. On the walls of the temple there is a huge amount of documents and photos. It is not only the current

\section{Congress decided}

At the final session it was noted that the reports and proceedings of the Congress reflected the recent direction of development of chemical science and technology, many current developments, and outlined the prospects for their development and use. The Congress confirmed once again that chemistry occupies a special position in the process of transition of our country towards sustainable development, allowing to solve a wide range of tasks from the study of the molecular basis of life and sustainability of the natural environment up to the creating of new materials and energy sources. Congress demonstrated the achievements of Russian and world chemical science in the areas of innovation developments to create new materials and technologies, including nanomaterials and nanotechnologies, the development of new drugs, electrochemical energetics, alternative energy resources and motor fuels from plant material, environmentally safe (i. e. green) chemistry and sustainable development problems. The

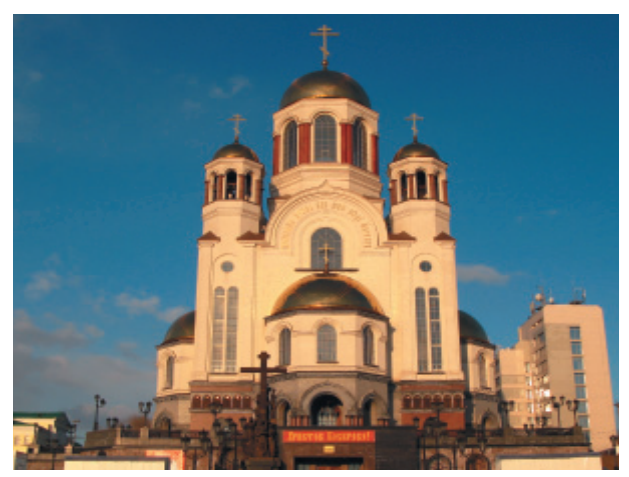

Cathedral, but a Museum complex. 20 to 25 minutes was allotted on examination of the Cathedral, since it was necessary after the tour to go to the evening session of the Congress.

It's a pity that the tour was short, because to see in town you can pretty much. But inexorable time is inexorable.

special attention was paid to the issues of chemical education and the fight against chemophobia.

The Congress draws the attention of the Government and of the Commission on modernization under the President of the Russian Federation on the inadmissibility of the mechanical merger of universities, academic institutions.

Congress believes that one of the most important social factors for successful implementation of the proclaimed by of leadership of the Russian Federation the strategy of modernization of the Russian economy through innovation is the availability of highly skilled scientific and engineering personnel. The development of such skills requires increased attention of society to secondary and higher technical education, as well as to schooling, which will tend to cause interest of pupils to study natural science subjects - mathematics, chemistry, physics, biology. In this regard, the participants of Mendeleev Congress consider the 
necessity to ask the Ministry of education and science of the Russian Federation to ensure the development and implementation of system of measures on improvement of training programs (including increasing the number of hours to study chemistry and physics in school) and teaching chemistry and physics in secondary school.

At the same time despite some successes the Congress believes that further development of chemical science and industries, chemical education and related sectors, with a glance of their significance and potential capacities, requires the adoption of urgent measures to accelerate the commercialization of results of fundamental researches and the improvement of legislation in matters of intellectual property. The providing investment, update technology and engineering, expanding of the attracting of talented young people in the chemical science and industry, strengthening of its social support also are required.

I offer my opinion briefly, which was outlined in several publications on the work of industry and academic institutions and universities. The ill-conceived reorganization of the Academy of Sciences, the strange association of universities, reduction of staff, low funding, the transformation of education in schools and institutions in services didn't contribute to the success of science. I want to remind you the statement, attributed to German Chancellor Otto von Bismarck: «the War is won by school teacher». On the ratio of expendi- ture on science and GDP, Russia ranks last among major developed countries. The relationship between the authorities and the scientific community is becoming more like - «I checked, you are not sick of me».

The very low prestige of scientists in recent years is disastrous for Russian science. In Canada the survey was conducted: "What an achievement more raises the patriotic spirit - the Nobel prize or the number of medals at the Olympic games»? Almost $75 \%$ of Canadians chose the Nobel prize. As the newspaper «Izvestia» wrote, the Sochi Olympics are more important than Stockholm for us.

The disappearance from the map of Russia more than 5,000 branch scientific research institutes and $\mathrm{KB}$ from 6000 in many ways reduced and opportunities to implement of developments of academic research institutes and universities to industry. I asked more than once - how many are the engineers in Russia? It seems that there is no accurate data. At the I Congress of engineers of Russia in the Kremlin in 2003, two speakers called the various numbers 15 and 11 million. On the Internet the exact figure is absent. More specific information about the number produced by our institutions of engineers is more than 400,000. There is the huge army of graduates, but not all they work in the specialty. Of course, it's repeated like a mantra «the engineers and scientists change the world». Why ENGINEERS go into other areas? It's not prestigious as science. The salary of engineers

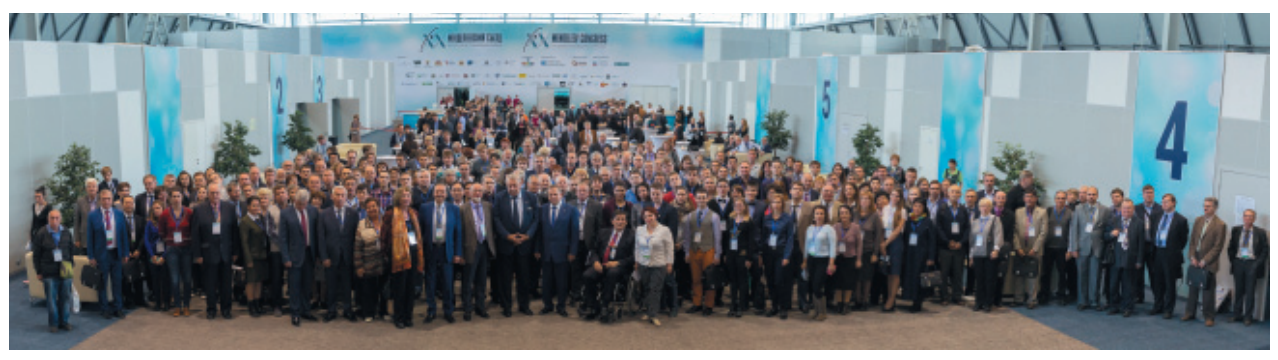


in Russia to 2016 in the regions in various sectors ranges from 11000-15000 to 100000 rubles and more. Of course our oilmen, working in difficult conditions receive high wages, it's no doubt. But why do engineers performing roughly the same work in the big cities and especially in Moscow, receive 3-5 times higher salary than in the regions, for example, in Novomoskovsk? You can certainly order to push Moscow not only to Kaluga region. What is next?

The taxes of thousands of Russian enterprises remain in Moscow, because these companies are registered in the capital (although working in the regions). Therefore the miners of oil, gas, chemists, metallur- gists, etc., although operating in very difficult conditions and toxic emissions, receive much lower wages than the Muscovites. Even the cities, where there are these enterprises, can hardly survive. I recall the commercial where the girl is drinking glass after glass of juice and to the comment of his dad: «My child, you will burst!» - answers: "And you, daddy, come in».

Does anyone still not clear that we need other laws by which the portion of taxes that is not going to the Federal centre, should stay there, where are the enterprises?

Again not to recall the wise men - «If you do not know where to drift, the tail wind does not help».

\section{Russian chemical society}

In the framework of the Congress a few hours on one of the evening meetings was allotted to the VIII report-electoral Congress of the Russian chemical society. D. I. Mendeleev (RKhO). I Congress of RKhO was held in 1991 in Rostov after the collapse of the Soviet Union. I was one of the delegates. The Statute was adopted and the President of the Russian chemical society was academician Yu. A. Zolotov.

In subsequent years, President of the society were elected academicians A.I. Rusanov, P. D. Sarkisov, A. Yu. Tsivadze. 90 Delegates from 125 selected in the regional organizations took part in the VIII Congress, including the author of these lines from Tula organization chemical society. Among the participants there are 22 academicians and corresponding member Q. Russian Academy of Sciences, 30 professors, 28 researchers and engineers.

The report on the work of the society was made by the President RKhO named D. I. Mendeleyev, academician A. Yu. Tsivadze. He noted the difficult situation in almost all public organizations, the lack of assistance of regional authorities, ministries, lack of facilities, poor funding. Aslan Yusupovich spoke sharply about the same at the opening of the XX Congress in the presence of two thousand participants of the Congress, the representative of the Russian President in the Urals Federal district (district is larger than the area of Germany, France, UK, Spain together), heads of the Russian Academy of Sciences, FANO, Governor of the Sverdlovsk region and others.

After the collapse of the USSR RKhO named D. I. Mendeleev exists on a very modest budget of a minimum membership fee. The reason is the status of public organizations, lack of funding from companies, universities, research institutes

In foreign chemical societies, the situation is different. For example, in the UK chemical society is a professional organization, which consists of about 55,000 members. Society has a big budget that allows it to allocate funds for awards, scholarships, publishing of journals. 
It is urgent to improve the activity of the Russian chemical society.

The proposals for the amendment of the Charter concerning differential membership with the appropriate variety of entrance and annual membership fees was introduced by A. Yu. Tsivadze and then approved by the delegates. The amendment of the Charter to the extent that the members of the society can be along with public organizations as legal entities is important. To formulate proposals for the Board of Trustees was entrusted with the presidency of the society. Moreover, an extremely useful experience of boards of guardians is known on example geographical and military history societies. It is decided to establish a gold medal RKhO named D. I. Mendeleev, which will be awarded for outstanding achievements in the field of chemical Sciences and technology. The medals will be awarded annually to Russian and foreign scientists, the representative of the domestic industry.

Of course, it's not all kindly in the activities of the society. There are very few young members of society and, in my opinion, a great loss in the work of the society is the long pause (mainly due to financial issues) of the publication of the popular Newsletter "Chemistry in Russia».

Yes, without a good funding the conducting of conferences, competitions, etc. is almost impossible. Once again, I note that these issues really can be solved only with the involvement of collective members, who will be able to sponsor NTO. But still I believe that many of the problems of the chemical society, NTO miners, metallurgists, mechanical engineers, etc. are associated with a very poor awareness among engineers, scientists, especially the young about the challenges societies on the prestige of participation in the work of these organizations. There are virtually no ap- pearances on television, radio, publications in Central and regional of press managers NTO, members of the Presidium with many high academic regalia.

For a long time I thought about the difficulties of public works. Many organizations became private and not everywhere there, and in the state organizations, the leadership understands the necessity of participation in the work of the Russian engineering Academy (RIA), the International Academy of ecology (MANEB), the Union of scientific and engineering associations (USEA), the Mendeleev chemical society and others.

And if there are such and the other enough problems, primarily young employees, the engineers are not eager to participate in public life. We all know that part of the activities carried out during working hours and they are forced to take their vacation days. And with a glance of modest wages, especially at the young employees, but their excessive pragmatism - the result is known. The very likely result is to remain all us without young reserve.

Director of the Institute of physical chemistry and electrochemistry of RAS, academician-Secretary of the Department of chemistry and materials science of RAS A. Yu. Tsivadze was reelected President of the society, and candidate of biological sciences N. R. Kosinova was reelected scientific Secretary. Vice-presidents, the Bureau RKhO and Board members were elected. From the Tula region the Chairman of the regional Board of the Tula chemical society, Professor of the Tula University, V.M. Panarin was elected, and the main scientific employee of "NIAP-Katalizator», professor E. Z. Golosman was re-elected Deputy Chairman of the regional Board (since 1967) which was member of the Central Board since 1994. 
The pleasant and promising conclusion of the Congress was the message that the next Mendeleev Congress will be dedicated to the 150th anniversary of the discovery of the periodic law and the 150th anniversary of the formation of the Russian chemical society (formerly the Russian physicochemical society). Naturally, the Congress will be held in St. Petersburg, in which all significant of the above events were happened. This event will occur in 2019.

\section{Visit to Dmitry Ivanovich}

About 200 museums are located in Saint-Petersburg and I will allow to give advice to future participants of the Congress and, of course, to all who visit St. Petersburg to the landmark forum - to visit the $\mathrm{Mu}$ seum of Dmitry Ivanovich Mendeleev. The Museum is located in a historic building of the Twelve colleges of the Saint Petersburg state University on Vasilievsky island. The Museum was founded in 1911 on the initiative of participants of II Mendeleev Congress and is located in the former government apartment of Dmitry Ivanovich, where he lived for almost a quarter century as a Professor and head of Department of the University.

At the invitation of D. I. Mendeleev students could come for advice, without leaving the University building, through the door leading to the apartment of the Professor. The Professor's study, a huge library collected by him, many books which were presented to him by colleagues and friends survived. The major role plays the archive of scientist.

In this apartment were arranged the scientific and artistic «environment», which were: the sculptor Peter Klodt, artists Ivan Kramskoy, Arkhip Kuindzhi, Ilya Repin, Ivan Shishkin, music critic, art historian Vladimir Stasov, the composer Alexander Borodin, the physiologist Ivan Sechenov, Admiral Stepan Makarov, poet (brother-inlaw periodic) Alexander Blok. The Museum has a fine collection of paintings, collected by D. I. Mendeleev. The Desk preserved: where Mendeleev invented his periodic law, which worked for 25 years; old camera; chess; a huge library; a large collection documenting the life and scientific activity;
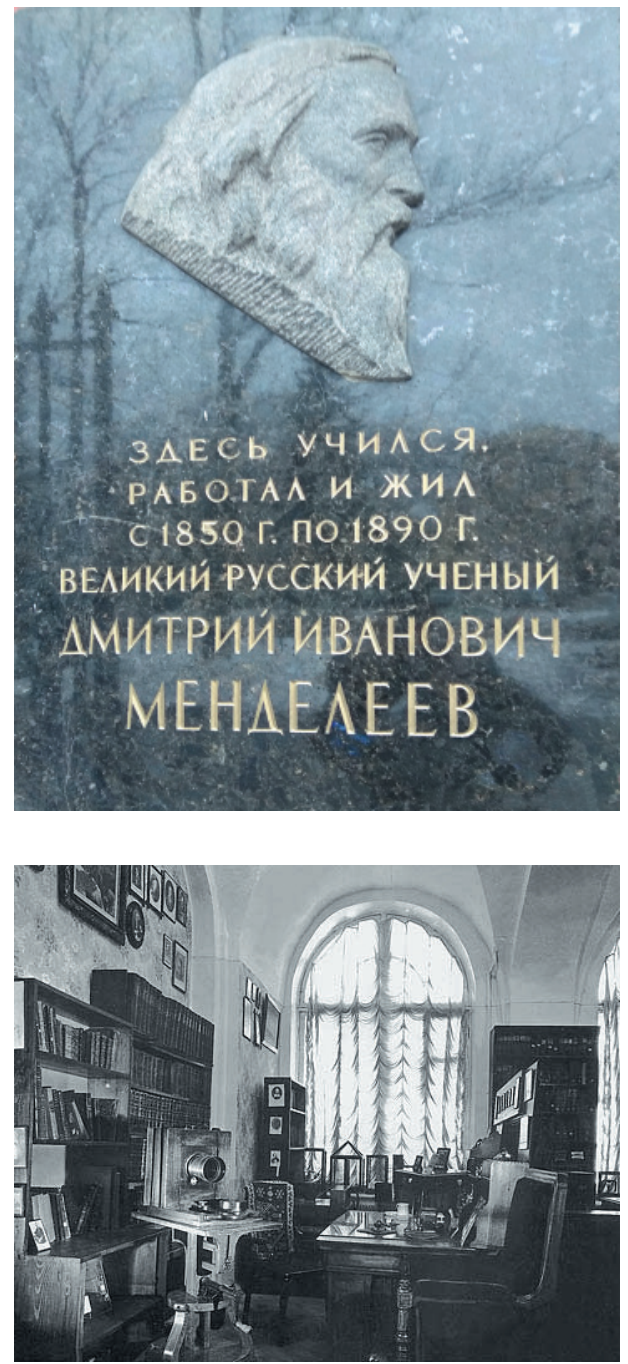

Office of D. I. Mendeleev in St. Petersburg University 
the layout of the icebreaker, invented by Mendeleev the instruments on which he conducted researches, map with marked cities which Mendeleev visited, and a tablecloth with autographs of famous people of the time preserved too. Thousands of people, among whom was Nobel laureate I. Prigozhine, G. Seaborg, L. Pauling, P. Kapitza, the President of France Jacques Chirac, a famous Russian and foreign scientists visit the Museum annually. I believe that no chemist, physicist, Metallurgist, physician, metrologist, oilman, Explorer, Collier, an economist, a meteorologist, school teacher, University lecturer, researcher, artist, com- poser, sculptor and balloonist, the student, the student can not go to a Museum scientist, a genius of science.

The Congress appealed to the President of the Russian Academy of Sciences and the Ministry of foreign Affairs, International organizations with a request to declare 2019 «International year of the Periodic table of chemical elements».

And yet, after Irakli Andronicov want to say: «Let's raise the level of our discussions to the level of backroom conversations». Meantime, good luck to the future participants of the world events.

\section{Epilogue}

Favorite example from history. Napoleon was losing the company in Egypt. A military camp was surrounded and fired by the enemy. Napoleon ordered to gather in

the safest place of the camp Donkeys and Scientists, considering that in the first place to save the Transport and Science.

\section{In Russian}

В последние годы написал много статей, посвященных российской науке, образованию, реформированию РАН, конкурсам «Инженер года», научно-

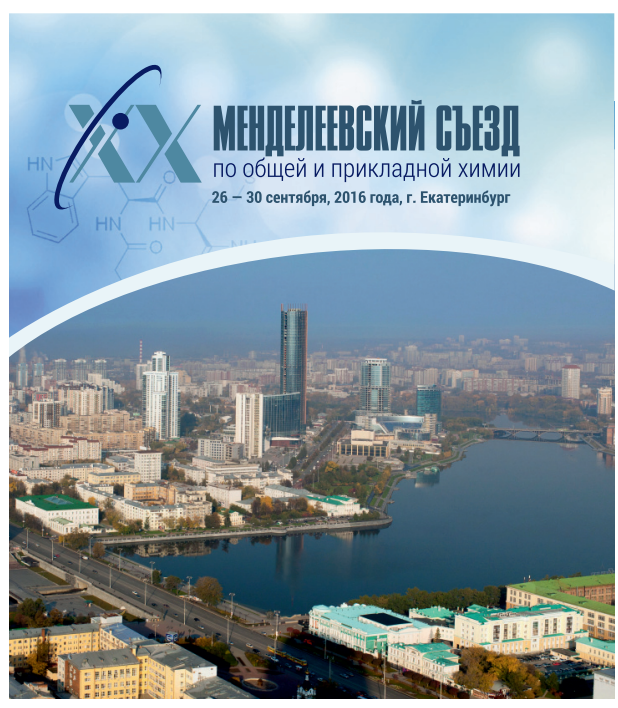

техническим обществам, чиновникам, гибели отраслевых институтов. Статьи были опубликованы в центральных, областных, городских газетах и журналах. Откликов от специалистов из НИИ, вузов, заводов, РАН и даже из Госдумы, правительства, от губернаторов было много. Получил как-то письмо от коллеги из новосибирского Академгородка с вопросом: «А есть ли хоть какие-либо сдвиги после Ваших многолетних набатов?» Мой ответ дословно был такой: «Если бы только мой набат. Выступают сотни тысяч известных ученых и инженеров с искренним стремлением не дать разрушить достижения страны непродуманными реформами. Можно только позавидовать КПД паровоза отца и сына Черепановых». И все же, если ты 
борешься - можешь проиграть. Если не борешься - ты уже проиграл.

Недавно в столице Урала, Екатеринбурге, состоялся ХХ Менделеевский съезд по общей и прикладной химии.

В один из дней работы съезда состоялся и отчетно-выборный съезд Менделеевского химического общества.

Озвучил приветствие съезду президента РФ В.В. Путина полномочный представитель главы государства в Уральском округе Игорь Холманский. Съезд приветствовал губернатор Свердловской области Евгений Куйвашев. Руководитель федерального агентства научных организаций Михаил Котюков поздравил съезд от имени председателя Правительства РФ Д. А. Медведева.

Вице-президент РАН академик Сергей Алдошин выразил уверенность, что съезд позволит определить основные пути развития отрасли на ближайшие пять лет.

Председатель Уральского отделения РАН академик Валерий Чарушин на съезде и при открытии выставки напомнил девиз заводчиков Демидовых: «Делами, а не словами».

Съезд приветствовала президент Международного союза по теоретической и прикладной химии (ИЮПАК) член-корреспондент РАН Наталья Тарасова.

Приветствовали съезд по видеообращению бессменный президент многих Менделеевских съездов академик Олег Нефедов и председатель Российского фонда фундаментальных исследований академик Владимир Панченко.

Президент Российского химического общества академик Аслан Цивадзе напомнил, что еще недавно российские города, кроме Москвы и Санкт-Петербурга, не были готовы к приему многотысячного съезда.

Столица Урала сумела организовать столь грандиозное мероприятие.

Организаторами съезда являлись Российская академия наук, Уральское отделение Российской академии наук, Федеральное агентство научных организаций, Правительство Свердловской области, Российское химическое общество имени Д.И. Менделеева, Министерство образования и науки Российской Федерации, Уральский федеральный университет имени первого Президента России Б.Н. Ельцина, Национальный комитет российских химиков, Российский союз химиков. Съезд проводился под эгидой Международного союза по теоретической и прикладной химии (IUPAC).

\section{Первый Менделеевский}

Первый Менделеевский съезд памяти Д. И. Менделеева «Вопросы общей химии, отраслей химической технологии и проблемы приложения химии в разных отраслях науки и техники» состоялся в Санкт-Петербурге в 1907 г. В работе съезда приняли участие представители 80 городов. Позже съезды проводились в Москве, Ленинграде (Санкт-Петербурге), Казани, Харькове,

Киеве, Алма-Ате, Баку, Ташкенте, Минске, Волгограде.

Тематика съездов охватывает основные направления развития химической науки, технологии и промышленности, химического образования и взаимодействия бизнеса с наукой и промышленностью, что существенно отличает их от обычных тематических научных конференций. Менделеевские съезды органи- 
зуются с интервалом в четыре-пять лет в крупнейших научных центрах страны и определяют пути развития химической науки и промышленности России.

В крупнейшем Российском научном форуме в Екатеринбурге приняли участие около 2000 делегатов, в том числе 300 иностранных ученых, а также представители компаний, занимающихся производством химических продуктов и материалов.

Среди 2000 участников XX съезда нобелевские лауреаты, более 100 академиков и членов-корреспондентов Российской академии наук, несколько сотен профессоров и кандидатов наук, 700 молодых ученых. В работе съезда также приняли участие президент Российской инженерной академии, членкорреспондент РАН, лауреат премии Правительства РФ Б. В. Гусев и другие действительные члены этой академии; академик, лауреат Государственной премии и премии «Энергия» В. Н. Пармон; академик РАН, заслуженный нефтехимик СССР, лауреат премии Правительства РФ С.Н. Хаджиев; лауреат премии Правительства, академик В. В. Лунин; академик, лауреат Государственной премии М.П. Егоров и др. С устными и стендовыми докладами выступили более 1100 ученых. В пяти томах материалов съезда опубликовано около 2500 тезисов докладов от имени 7800 авторов на русском и английском языках.

Обсуждение многих химических проблем, и в том числе химического образования и преподавания в РФ, взаимодействия химической науки и бизнеса, актуальных проблем азотной промышленности, помимо пленарных, устных и стендовых докладов, проводилось и в рамках девяти секций, трех международных симпозиумов, 10 круглых столов, которые представляют великолепную площадку для дискуссий специалистов науки и промышленности, определяющих направление и развитие металлургической, нефтехимической и др. отраслей промышленности.

Конечно же, осуществление столь масштабного мероприятия было бы затруднительным без финансового вклада спонсоров и десятков организаций.

Большую помощь в проведении съезда оказали руководство и члены

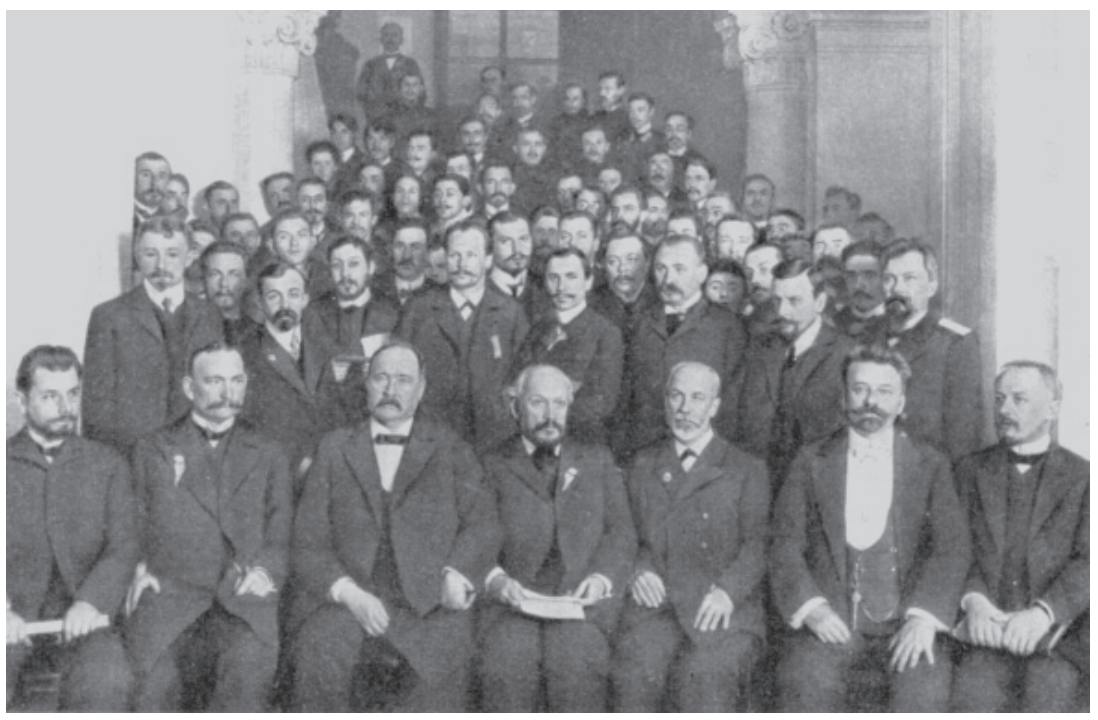


оргкомитета, московские и уральские специалисты, ученые Екатеринбурга и, конечно, сотни молодых волонтеров (студенты и аспиранты) в красивых футболках с надписью «Я люблю химию». С благодарностью надо отметить и гигантскую работу ученых секретарей

\section{Съезд в Таврическом}

Конечно же, читать, слушать рассказы, смотреть по телевидению весьма интересно, но, безусловно, ничто не заменит личное участие в съездах.

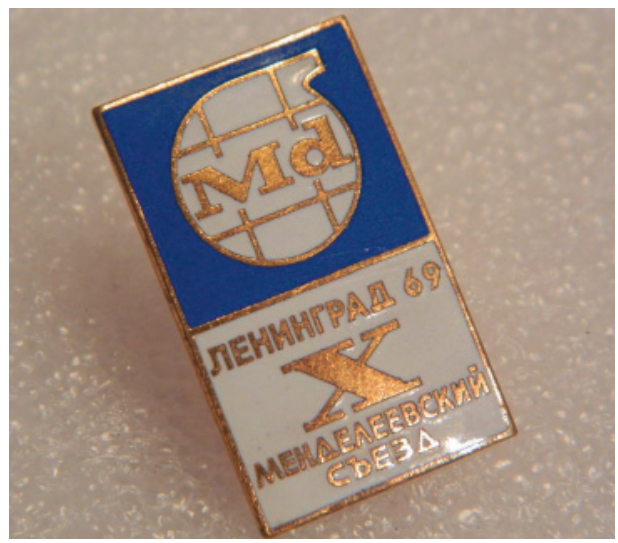

Мне посчастливилось в жизни участвовать в нескольких Менделеевских съездах в Ленинграде, Минске, Москве, Волгограде... Самым незабываемым, конечно, было участие в Х Менделеевском съезде в Ленинграде в 1969 г., который был посвящен 100-летию открытия Дмитрием Ивановичем Менделеевым периодической таблицы. Как говорится, с открытым ртом я смотрел на знамени-

\section{Король Генрих IV}

Раскручивая ленту памяти, вспомнил и возможность посещения участниками съезда театра Аркадия Райкина и впервые услышанные и увиденные мной сценки тогда еще не очень известного в стране блистательного Михаила Жва- съезда доктора химических наук, профессора Ю. Г. Горбуновой и кандидата химических наук О.А. Кузнецовой.

Местом проведения ХХ съезда был выбран г. Екатеринбург - крупнейший центр химической и металлургической промышленности России, столица Урала. тых организаторов и участников съезда, проводившегося в Таврическом дворце Ленинграда. В Х съезде приняли участие 2000 человек, и в том числе много иностранных гостей. Назову несколько фамилий: нобелевский лауреат Н.Н. Семенов, академики С. И. Вольфкович, Н. М. Жаворонков, В. И. Гольданский, И. В. Тананаев, Я. К. Сыркин, заместитель председателя Совета министров В.А. Кириллин, министр образования В.П. Елютин и десятки известнейших ученых мира. А какие доклады сделали открыватели новых элементов - легенда науки академик Г.Н. Флеров (открыл 104 элемент - резерфордий, и в честь Флерова 114-й элемент назван флеровий), председатель комиссии по атомной энергии США Г. Сиборг (синтезировал плутоний, а совместно с другими учеными открыл америций, кюрий, берклий, калифорний, эйнштейний, фермий, менделевий - в 1997 г. в честь Сиборга назван 106-й элемент - сиборгий), доклады министра химической промышленности Л.А. Костандова, директора Института катализа академика Г.К. Борескова!

нецкого в исполнении Райкина. К сожалению, рядовым участникам съезда не смогли дать возможность приобрести билеты в Большой драматический театр под руководством знаменитого режиссера Георгия Товстоногова. Явившись 
к началу спектакля в театр и поговорив с администратором, объяснившим мне, что билеты сюда - это местная валюта, я понял безнадежность попадания в театральный зал. Шел небольшой дождик, я прошелся вдоль реки Фонтанки, где расположен театр с Думой... Как же попасть на спектакль? И, наконец, пришла отчаянная мысль, реализация которой присуща только безрассудной молодости. Дожидаюсь антракта, снимаю свой нейлоновый плащ, засовываю его в водосточную трубу и вместе со зрителями, вышедшими в перерыве на улицу покурить, захожу в одну из лож и стоя смотрю два акта спектакля «Король Генрих IV» У. Шекспира с великими актерами Сергеем Юрским, Олегом Борисовым, Евгением Лебедевым, Ефимом Копеляном, Владиславом Стрежельчиком, Олегом Басилашвили, Николаем Трофимовым и др.

\section{Периодическая законность}

Но вернемся в Екатеринбург. От имени моих соавторов, специалистов «НИАП-Катализатор», НАК «Азот», «Нижнекамскнефтехим», я представил на съезде два доклада (по катализаторам метанирования и очистки пропана), а на круглом столе «Актуальные проблемы азотной промышленности» (под руководством члена-корреспондента РАН В. Г. Систера) - доклад о промышленных катализаторах, разработанных и производимых в «НИАП-Катализатор».

Десятки секций и круглых столов, разбросанных в гигантском центре «Екатеринбург-ЭКСПО», тысячи докладов прослушать, конечно, было невозможно, несмотря на очень жесткую программу (начало заседаний съезда в 9 утра, окончание в 20 часов). Упомяну несколько самых престижных.
И уже по прошествии десятков лет я думаю, как тогда мне, молодому специалисту, сотруднику филиала Государственного института азотной промышленности, повезло принять участие в съезде и сколько это мне дало в дальнейшей работе и, надеюсь, в передаче приверженности к науке моим молодым коллегам в созданных секторе, лаборатории, которые носили название ИКАР (исследование катализаторов, адсорбентов, реакций). ИКАР, думаю, кое-что сделал для науки, промышленности. Сотни статей, книг, докладов, патентов, разработанные катализаторы внедрены на почти 200 предприятиях СССР, России, СНГ и дальнего зарубежья. Но, видимо, ИКАР, да и многие отраслевые и академические НИИ, близко подлетел к солнцу, и теперь его уже, к сожалению, нет.
Д.И. Менделеев много лет тому назад говорил: «Периодическая законность первая дала возможность видеть неоткрытые еще элементы в такой дали, до которой невооруженное этой законностью химическое зрение до тех пор не достигало, и при этом новые элементы ранее их открытия рисовались с целой массой свойств». Эти предсказания вскоре блестяще оправдались. И в наши дни открытие новых элементов продолжается. Этому свидетельствует доклад Ю. Ц. Оганесяна и С. Н. Дмитриева об открытии новых сверхтяжелых элементов с атомными номерами 113-118 периодической таблицы Д.И. Менделеева. Открытие новой области стабильности сверхтяжелых элементов поставило целый ряд новых вопросов, и в частности, где границы периодической таблицы 
Д. И. Менделеева. Академик Юрий Оганесян вместе с двумя американскими учеными был номинирован на Нобелевскую премию по химии 2016 г., но премия досталась другим ученым. Наконец, на днях решен вопрос и один из вновь открытых элементов теперь будет носить имя Оганесяна. Также решен вопрос о присвоении имени одному из новых элементов - московий (в честь Московского региона (г. Дубна), где расположен Объединенный институт ядерных исследований, в котором совместно с Ливерморской национальной лабораторией (США) были проведены эксперименты для обнаружения новых элементов). Правда, как заметил однажды академик Оганесян: «Открытия у нас делают одни, а право присвоить названия принадлежит другим».

По наиболее близкой тематике моей много лет специализации (катализаторы) наибольшее впечатление произвели доклады академика РАН В.И. Бухтиярова, профессора В. М. Капустина, академика А. Г. Дедова, члена-корреспондента 3. Р. Исмагилова. Упоминаю только несколько докладов (из множества), которые лично удалось прослушать.

Для российской и мировой науки значимость съезда была подчеркнута участием президента РАН академика В. Е. Фортова с докладом «Химические элементы в экстремальных условиях». Речь в сообщении В. Е. Фортова шла о поведении химических элементов в условиях сверхвысоких давлений. При этом резко меняются их свойства. В бли-

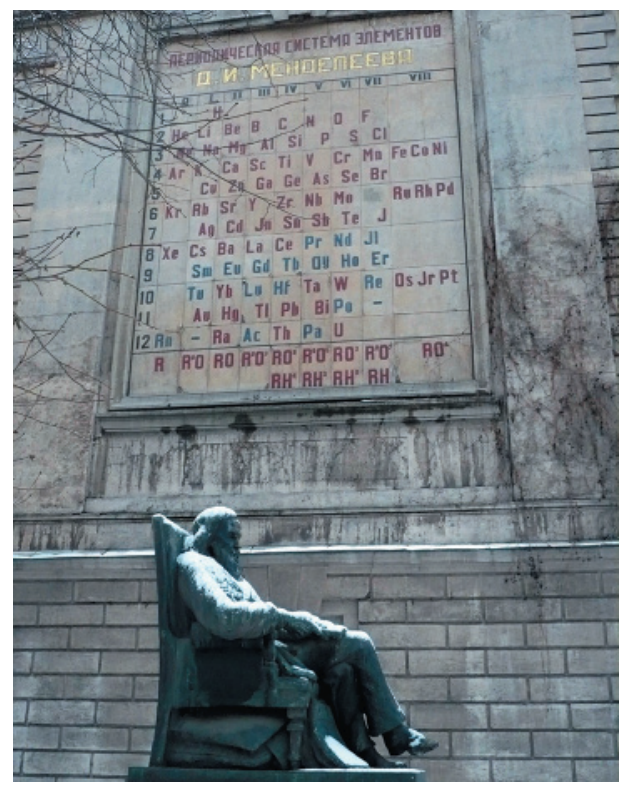

жайшие годы возможно и открытие химических элементов, не вписывающихся в таблицу Менделеева, что, несомненно, заставит расширить границы познания.

Безусловно, блестящий доклад нобелевского лауреата Даниэля Шехтмана профессора «ТЕХНИОН» (г. Хайфа, Израиль) и Университета Айовы (США). До работ Д. Шехтмана никакой революции в науке о кристаллических материалах не предвиделось. В течение более 10 лет его работы не хотели даже печатать, критиковались. Но он упорно доказывал значимость своих научных представлений. В итоге Нобелевский комитет отметил, что его открытия заставили научный мир пересмотреть свои взгляды о природе материалов. Великолепный пример преданности науке и упорства в достижении цели.

\section{А где производственники...}

Хотел бы отметить и проблемы с аудиторией наших докладчиков. Требование времени - внедрение разработок, а производственников (техноруков, на- чальников цехов, ведущих и главных инженеров) крайне мало. Причина недопонимание собственников и руководства предприятий, недостаточная 
информированность заводов и непомерная стоимость практически всех научных конференций, проводимых, по крайней мере, последние 15-20 лет. Вряд ли из-за текущей производственной занятости, а также высоких затрат заводчане даже ближайших регионов от места проведения какой-либо конференции массово могли бы участвовать в научных форумах по 4-5 дней. Но вполне реально было бы организовать доставку инженерно-технических работников поочередно хотя бы на денек. Необходимо также направлять приглашения на наши конференции не только директорам и главным инженерам, но надо звать, информировать персонально и их замов, начальников производств, цехов и т. д. Помню, в Нижнекамске главный инженер ОАО «Нижнекамскнефтехим» привел на конференцию «Инновационные нефтехимические технологии» около десяти директоров заводов, входящих в состав комбината. И каждый из них кратко рассказал, какие проблемы есть у них в производстве. Заводчане обозначили задачи и просили ученых эти проблемы решить. Иначе, как и происходит ныне, научные сотрудники рассказывают другим научным сотрудникам о своих достижениях, которые надо непременно внедрять. Новинки достижения российских разработчиков до производственников не доходят, а главное с практиками не обсуждаются. Отсюда, возможно, во многом иллюзии разработчиков из вузов и академических НИИ, не представляющих в полной мере (в отличие от специалистов отраслевых институтов) сложнейших проблем с масштабированием своих достижений.

Вспоминаю, как на одной из конференций «Научные основы приготовления и технологии катализаторов» академик И. И. Моисеев после своего пленарного доклада заметил, что прослушал огромное количество сообщений с использованием прекрасных современных методов, отличных приборов, а новых промышленных катализаторов мало!

Наш съезд также не исключение, а ведь он посвящен как фундаментальным работам, так и прикладной химии. Отсюда также во многом невостребованность российской науки, хотя, конечно, есть и много других причин. О них чуть ниже.

\section{И снова об образовании, или Вновь с рыбным обозом - в Москву, Санкт-Петербург, Новосибирск...}

Конечно, много вопросов было связано с вузовским и школьным образованием. Не могут, не должны наука, образование, медицина быть услугами.

Остановлюсь на проблеме закрытия ряда вузов. Особенно это болезненно для регионов. Да, можно усилить несколько десятков университетов в Москве, Санкт-Петербурге, Новосибирске и других научных центрах. Конечно же, кто будет спорить - нужны хорошие институты с современной базой при- боров и высококвалифицированными преподавателями. Да, хорошо бы все они были на уровне Массачусетского, Калифорнийского, Индийского... технологических институтов, или нашего Физтеха. Но это же нереально.

Но на учебу в эти вузы смогут приехать 15-20\% подростков - остальных родители не смогут финансово обеспечить. К тому же у большинства вузов нехватка мест в общежитиях. Думали ли авторы идеи о сокращении количества 
вузов до минимального о том, сколько выпускников этих вузов вернутся на работу в провинцию после искушения жизнью в столице и других городах?

По данным президента РАН и председателя комитета по науке Госдумы, почти 80 \% выпускников столичных вузов, приехавших на учебу из различных городов, остаются в мегаполисах. Кто же будет работать на заводах, в КБ, НИИ на российских просторах?

Для укрепления провинциальных вузов надо, как это делалось когда-то много лет тому назад, направлять в них (конечно, при их согласии и с предоставлением на первом этапе служебных квартир с правом их приватизации, скажем, через 7-10 лет) преимущественно молодых кандидатов и докторов наук из ведущих вузов и НИИ страны.

Конечно, необходимо «освежать кровь», устанавливать связи с различными научными школами, а не проводить механическое сокращение студентов и преподавателей. И не лишать регионы возможности получения образования и очагов культуры. Как бы ни пришлось вспомнить старую шутку: на вопрос, в какой институт легче всего попасть, следовал ответ - в институт Склифосовского.

В Новомосковске в 1958 г. был организован филиал Московского химико-технологического института (ныне НИ РХТУ). Еще недавно численность очных, заочных российских и иностранных студентов составляла около 5000. Огромные корпуса, стадион, общежития. Выпускниками этого вуза (технологами, механиками, энергетиками, экономистами) в течение многих лет были обеспечены наши гиганты - НАК «Азот», «Проктер энд Гембл», «Гипс Кнауф», ГРЭС, «НИАП-Катализатор» и другие предприятия Новомосковска, Тулы, Ефремова, Щекино. Выпускники НИ РХТУ им. Д. И. Менделеева работают в десятках городов России.

Чьи мудрейшие решения привели к резкому сокращению студентов, преподавателей? Еще немного, и город химиков, энергетиков и регион останутся без вуза...

Давно размышляю, кто выдвигал, визировал, назначал министров А.Э. Сердюкова, Д. В. Ливанова, деяния которых в области науки, образования, армии еще долго будет расхлебывать страна?

Пора уже решать и вопросы выпуска бакалавров (недоделанных инженеров).

Кто же будет работать на высокотехнологичных предприятиях? Необходимо отметить, что спрос на бакалавров в промышленности практически отсутствует. Похоже, что страна вернулась в тридцатые годы прошлого столетия, когда надо было в спешке готовить на рабфаках технических специалистов. Известно, что даже инженеров приходится доучивать на предприятиях применительно к задачам производства, отрасли. Нужны хорошие полновесные инженеры. А вместо бакалавров надо увеличить подготовку квалифицированных техников и лаборантов в техникумах и колледжах. При необходимости, по крайней мере, в вузах, испытывающих недобор абитуриентов, студентов можно, на мой взгляд, так же готовить техников и лаборантов. Тем самым будет обеспечена и загрузка преподавателей этих вузов и использование, как правило, более богатой, чем в техникумах и колледжах, учебной базы.

Если государству больше нужны высококвалифицированные рабочие, остались же еще техникумы, колледжи, профессиональные училища. Если их 
недостаточно и нужны в XXI веке более квалифицированные рабочие, давайте выпускать их дополнительно в технических вузах. Общество получит и высококвалифицированных рабочих. Сохранится хорошая база на основе вузов, и убережем преподавательский корпус. Напомню, что в развитых странах доля высококвалифицированных рабочих доходит до $50 \%$, а в России - 5-10\%.

Технические вузы, особенно расположенные в промышленных регионах, однозначно надо сохранять, но и, конечно, укреплять их материальную базу и преподавательский корпус, и в том числе с привлечением, как отмечалось выше, специалистов из ведущих НИИ и заводов. Студенты этих вузов наиболее удобно и целесообразно будут проходить практику на близлежащих предприятиях и, конечно, именно они в первую очередь смогут пополнять инженерный корпус в своих регионах. Неужели не ясно, что выпускники МГУ, ЛГУ, НГУ предназначены в основном для работы в РАН, аналитических центрах и не смогут решить проблемы с инженерными кадрами.

Давно обсуждается вопрос привлечения в вузы профессоров и доцентов, работающих в НИИ и на промышленных предприятиях. Именно симбиоз вузовских преподавателей с совместителями, начатый когда-то легендарным Московским инженерным физико-техническим институтом, продемонстрировал высокую эффективность в подготовке студентов и аспирантов.

Отличные результаты в подготовке студентов и аспирантов показывает ка- федра катализа Новосибирского университета, возглавляемая академиком РАН, директором ИК СО РАН В.И. Бухтияровым. Значительная часть преподавателей является сотрудниками ИК СО РАН, где к тому же студенты и аспиранты могут работать над реальными проблемами и слушать лекции ведущих специалистов, а в дальнейшем и работать в знаменитом Институте катализа.

К сожалению, в ряде вузов картина совершенно иная. Выполняя указ президента о повышении зарплат работникам вузов, идет вымывание совместителей, числящихся на 0,1-0,5 ставки, тем самым как бы повышая среднюю зарплату вузовским преподавателям. Для кого этот камуфляж? Кого обманываем? Лишаем студентов, аспирантов контактов с ведущими практическими специалистами. И прежде всего кто же будет готовить из студентов инженеров без специалистов НИИ и заводов?

На президентском Совете по науке и образованию говорилось о потере популярности инженерного образования, нехватке квалифицированных инженеров, ставшей сдерживающим фактором развития экономики, и о необходимости приблизить образование к производству. О том, что студентов должны учить педагоги, знающие современное производство, что настоящий вуз - это вуз, где есть наука, для чего Минобрнауки предстоит устранить избыточные барьеры, вроде запретов на совместительство, для тех, кто занимается наукой или работает на реальном производстве. Изменений пока не видно. Какие же еще нужны указания?

\section{И Хирш нам снится}

И еще раз о рейтинге ученых, инженеров, о цитировании, индексе Хирша.

Как можно сравнивать ученых, преподавателей, инженеров и делать оценку 
их труда по совершенно разным публикациям? Один написал обзорную статью, которую много цитируют. Другой статью по новым результатам, которую, возможно, будут цитировать через несколько лет. Как сравнить время на подготовку большой статьи, но одной и 2-3 небольших статей? Как быть, если ряд материалов на определенных этапах, может быть достаточно продолжительных, являются закрытыми и авторы не имеют возможности их публикации? Кроме того, цитируемость зависит и от количества исследователей в данной области.

Индекс Хирша - важная, но далеко не единственная определяющая оценка уровня научного сотрудника. Повторю: многократные высказывания, произносимые в научном сообществе. Индекс Хирша не может служить абсолютным, объективным критерием оценки деятельности ученого. Он отражает суммарный результат работы, а не эффективность.

\section{Ab ovo (лат. - от яйца)}

На съезде, круглых столах, в кулуapax, конечно, обсуждались вопросы реорганизации РАН. Прошло три года. Достигнуты ли результаты? На мой взгляд, кроме затрат (неразрешимые, как мне кажется, противоречия между РАН и ФАНО), эта реформа ничего не улучшила.

Конечно, к работе РАН много вопросов, но к кому их нет?

Да, кто не помнит о проблемах не только в РАН, отраслевых НИИ, пусть посмотрит цифры падения ВВП, а также ежемесячные, ежегодные сводки Следственного комитета и других силовых структур о различных ведомствах, и в том числе известных государственных персонах. Да, надо чистить ряды научного сообщества, и в первую очередь от голых администраторов. Но неплохо бы и депутатскому корпусу, так рьяно поддерживающему неподготовленный закон о реорганизации РАН, также почистить свои ряды, тем более после выступления лидера партии ЛДПР, заявившего, что в академии все старые, и что после 40 лет мозги для творчества иссякают. Или мозги нужны только ученым?
За 300 лет в России сложилась академическая наука. Почему нужно ее ломать через колено? Если плохо работает вокзал, его же не сносят, а меняют начальника.

На одном из заседаний президент Сельскохозяйственной академии наук Геннадий Романенко отметил, что «во все времена наши правители вспоминают о науке, когда в стране возникают проблемы, а когда с помощью науки они устраняются, начинают ее реформировать».

О каком понимании разрушительного процесса ликвидации и даже - в другой формулировке - якобы реорганизации идет речь, когда во время дебатов в Госдуме по закону о РАН кандидат экономических наук вице-премьер О. Голодец сообщила, что после реформ отраслевая наука живет и процветает. И академия после преобразований будет жить хорошо. И это заявление чиновник высшего ранга делает депутатам, всей стране, и в том числе всем нам, сотрудникам разгромленных отраслевых НИИ.

Много лет назад, когда начали крушить отраслевые институты, беседовал с рядом академиков и ведущих ученых РАН. Доказывал, что если не 
остановить разгром отраслевых НИИ, следующей будет Академия наук с ее гигантским имуществом в центре, как правило, крупнейших мегаполисов. Академики не вступили в ряды защитников. Хотя и возмущались, но тихо. Помните у Салтыкова-Щедрина: «Губернаторы стоят на коленях, но видно, что бунтуют»? К чему это, в частности, привело? Внедрять разработки стало проблематично. Академию все больше упрекают в том, что ее исследования оторваны от промышленности и так далее, при этом финансирование весьма скромное. И абсолютно неприемлемым является намерение в основном выборочного финансирования отдельных коллективов, что, безусловно, приведет к мелкотемью. Даже лучшим ученым и лабораториям неизменно нужна подпитка научных масс. Определять административно, какие научные коллективы необходимо прекратить финансировать, очень опасно и приведет к массовому оттоку научных сотрудников. Последствия этого катастрофически скажутся через короткое время. Об этом говорит и российский и мировой опыт. В России уже давно нет избытка ученых, и мы находимся по числу ученых на 10000 население где-то в третьем десятке.

Реформа же столь сложнейшей корпорации ученых, какой является РАН, затормозит развитие российской науки на многие годы. Академик, нобелевский лауреат И. Павлов о первых реформах молодой советской власти в 20-х годах прошлого столетия иронично высказался: «Я бы попробовал сначала на собаках».

Подтверждение необдуманности реформ - продолжающийся отъезд за рубеж талантливых инженеров и других специалистов. Повторю хрестоматийный пример. Германия, лишившаяся после войны заводов, оборудования, ведущих ученых и конструкторов, так и не смогла даже спустя десятилетия вернуть себе, например, первенство в самолетостроении.

Потери России только от отъезда наших талантов за рубеж от изобретателя телевидения В. Зворыкина и химика В. Ипатьева до нобелевских лауреатов К. Новосёлова, А Гейма в десятки раз превышают годовой бюджет российской экономики.

Вместе с утечкой за рубеж молодых, энергичных умов утекают и возможные патенты. Стоимость оформления патентов непомерно высока. Если патенты не подаются, высока вероятность перехвата разработок инофирмами. Что, государству не нужно закрепление изобретений за Россией? По числу удовлетворенных патентов в год РФ уступает США более чем в 15 раз, а Китаю - более чем в 40 раз.

Из истории человечества известно, что фундаментальные исследования рано или поздно заканчиваются прикладными результатами (лазер и тысячи других примеров). Да, наука является рискованной отраслью. Требуется около трех тысяч идей, чтобы получить один крупный реальный коммерческий продукт. Но даже при этом фирмы и государство получают огромную прибыль. Это надо знать всем, и в том числе малоподготовленным критикам науки.

Доколе до основания?.. А что потом? Все эти предложения напоминают «открыли все буквы, а слово прочитать не могут». 


\section{И кучера, и чиновники...}

Много вопросов и претензий в обществе вызывает прием в РАН чиновников. Что их туда манит? Конечно же, полагаю, престиж, создание запасных аэродромов и возможность занятия хороших должностей. Ну и пожизненная стипендия академиков и членов-корреспондентов не лишняя.

И все же, я думаю, на первом месте престиж, амбиции. Это было в царское время, в Советском Союзе и продолжается сейчас. Касается это и желания стать кандидатами и докторами наук тысяч чиновников всех рангов, особенно в области юриспруденции, политологии, социологии, истории...

Любопытный рассказ о желании стать академиком одного из царских военных министров. Собрали академиков, те не знают, что делать. Какое отношение он имеет к науке, какие научные труды? Один из руководителей императорской академии говорит, что все-таки он близок к царю. На что вольнодумный академик заметил, что кучер царской кареты еще ближе к царю, и даже сидит к нему спиной... Министра не избрали, а академика сослали.

Отдельная тема - кумовство, «крыши» в академии. Давно на моем Skype висит: «Есть ли в науке дедовщина?» Есть и еще какая! Но сия тема требует отдельных страниц и отдельной дискуссии.

«Мораль сей басни такова:

Иной ярлык сильнее льва».

\section{Эффективность научных разработок}

Все же, несмотря на все проблемы, можно привести много примеров эффективности научных разработок для «гражданки» и «оборонки». Остановлюсь на нескольких, близких мне по тематике, связанной с разработкой эффективных катализаторов, лежащих в основе 85-90 \% всех химических технологий, используемых в различных отраслях промышленности. Общий объем мировой продукции, производимой за год с помощью каталитических технологий, оценивается в 3 трлн долларов. При этом стоимость годового объема производства используемых для этого катализаторов не превышает 13-15 млрд долларов. Иными словами, доля стоимости катализаторов в производимой с их помощью продукции обычно не превышает долей процента. Вот что такое эффективные научные разработки! Приятно отметить, что среди 500 промышленных катализаторов, используемых в химии, нефтехимии, металлургии и других отраслях экономики России, более четырех десятков - это разработки моего родного Новомосковского института азотной промышленности («НИАП-Катализатор»)

\section{Катализатор - понятие стратегическое}

Несмотря на то, что производство катализаторов в России давно отнесено к так называемым критическим технологиям, доля импортных катализаторов, поставляемых в страну, неизменно растет и составляет для различных отраслей от $60 \%$ (азотная промышленность) до 90 \% (получение бензинов). Напомню, что с применением катализаторов производится большая часть химической и нефтехимической продукции. Катализаторы используются во всех отраслях для очистки технологических и выбросных газов. Страны-экспорте- 
ры при необходимости могут оказать огромное давление путем ограничения поставки необходимых катализаторов. Последствия такой жесткой политики весьма тревожны, ибо в настоящее время число стран, которые владеют полным комплексом технологий производства катализаторов нефтепереработки (отрасли промышленности, стратегической для экономики очень многих государств), оказалось меньше, чем число государств, владеющих технологией производства атомной бомбы.

Обсуждал проблемы санкций с рядом руководящих специалистов химкомбинатов. Упрекнул, что не помогают нам, отраслевым институтам, в итоге останутся без катализаторов. Ответ некоторых был обескураживающим. Ничего, купим в Китае. Как говорится, спасибо китайскому пролетариату за то, что освободил российский пролетариат от работы.

Науке все чаще предлагают делать все самостоятельно: и дорогостоящие исследования, и самофинансироваться, и проводить промышленное внедрение разработок. Как говорили в КВН: «Что такое маникюр? Это когда не сам себе грызешь ногти». И все же, как говорил нобелевский лауреат Петр Капица: «Основной стимул каждого творчества - это недовольство существующим».

Сокращаются производства катализаторов. Полностью закрыта крупнейшая в Европе катализаторная фабрика в городе Дорогобуже, которая была построена по разработкам и проектам ГИАП и его Новомосковского филиала. На фабрике производились тысячи тонн катализаторов мирового класса, в том числе созданных мною с сотрудниками.

Лишение должной поддержки отраслевой, академической, вузовской науки при столь недальновидном поведении государственных деятелей напоминает ситуацию, когда девушка вырывается от вампира, царапается, кричит. А он философски изрекает: «Ну что ты так орешь и нервничаешь? Мне же только таблетку запить».

Есть ли все же примеры создания новых эффективных промышленных катализаторов? Это, безусловно, разработки Института катализа СО РАН и новейшие разработки технологического института сверхтвердых и новых углеродных материалов в г. Троицке.

Классных исследователей в стране много, а список создателей промышленных катализаторов, способных довести свой продукт до внедрения, к сожалению, немногочислен. Еще раз приходится констатировать: разрушен мост РАН, вузов с отраслевой наукой. А пока проедаем «старый багаж».

Приведу несколько разработок нашего «НИАП-катализатор» (бывший филиал ГИАП) в г. Новомосковске.

Это катализатор для процессов метанирования (одна из стадий агрегатов синтеза аммиака). Срок его службы удалось продлить с 5 до 15-16 лет, а на трех заводах - до 22-24 лет. Подтвержденный экономический эффект от внедрения этих катализаторов составил несколько миллиардов рублей. Несмотря на экспансию инофирм, ими загружены практически все метанаторы в России и СНГ.

В последние несколько лет разработали с коллегами новый более эффективный катализатор метанирования с рядом значительных преимуществ. Но нет заинтересованности у руководства заводов при внедрении нового, пусть даже весьма эффективного катализатора. Видимо, они размышляют: а будут ли эти руководители еще работать? Зачем тогда им экспериментировать... 
И очень неплохой пример - катализатор разложения озона. Озон, при содержании его в воздухе уже выше тысячных долей процента, действует на человека сильнее синильной кислоты. Нами совместно с химфаком МГУ им. М. В. Ломоносова и фирмой «ТИМИС» разработаны высокоэффективные катализаторы, которые работают в тысячах установках во многих гражданских и оборонных отраслях и даже в адронном коллайдере в Швейцарии.

В Москве, на Западной водопроводной станции, озонируется (вместо хлорирования) в сутки $240000 \mathrm{M}^{3}$ воды, а остаточный озон разлагается на наших катализаторах.

Работы по созданию катализатора разложения озона отмечены престижной премией РАН имени выдающегося технолога академика В.Н. Ипатьева.

\section{Новый препарат защиты растений}

Создан новый фунгицид - медно-аммиачн-карбонатный раствор (МАКР), имеющий показатели выше средств защиты растений (бордосской смеси, медного купороса и др.). Препарат не содержит вредных примесей и позволяет осуществлять и внекорневую подкормку растений. Хранится долго, в любых емкостях и может использоваться и для обработки копыт животных, и для консервации древесных изделий. Препарат многократно более дешевый, чем существующие.
Имеются отличные результаты опытных испытаний в крупных сельхозпредприятиях и на дачных участках. Но на оформление документации в Минсельхозе и других центрах требуется непомерное многомиллионное финансирование. В связи с этим вспоминается мрачноватая шутка: чтобы вытащить гвоздь из вашей головы придется заплатить 100 тысяч рублей - Но у меня же полис! - По полису можем загнуть, чтобы не мешал.

\section{0бщественные академии}

Свой вклад в решение многих задач промышленности вносят и общественные академии, и в том числе крупнейшие - РИА, МАНЭБ, осуществляющие научную и инженерную деятельность по ключевым проблемам науки и техники практически во всех отраслях промышленности. В составе этих академий нобелевский лауреат, академик РАН Жорес Алферов, академик РАН Александр Ишлинский и многие другие академики и члены-корреспонденты РАН, выдающиеся государственные деятели и организаторы производств, лауреаты зарубежных премий, государственных и других премий РФ.
Наиболее полно и значимо итоги деятельности подводились на различных конференциях, пленумах и съездах инженеров России в 2003 г. (в Кремле), в 2010 г. и на недавно состоявшемся (май 2016 г.) в Москве, в Октябрьском зале Дома Союзов, Международном форуме

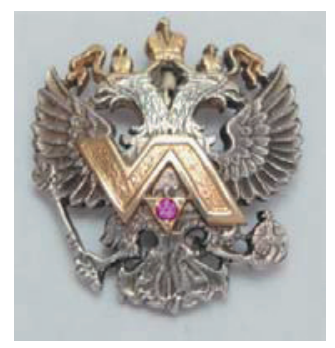

Золотой знак РИА 
«Устойчивое развитие и решение научно-технических проблем в различных областях творческой активности».

Начинается подготовка РИА к III съезду инженеров России, который, вероятно, состоится в Екатеринбурге. Будут блестящие выступления ученых, инженеров, руководителей предприятий. И в Кремле у меня, особенно после первого съезда, и, наверное, не только у меня была эйфория. Грандиозный сбор инженерной элиты, умнейшие решения.

А что далее в реальной жизни с наукой, образованием, критическим старением производственных фондов, ВВП? Далеко не столь радужно. Мне все это в нашей действительности напоминает, как знаменитый дирижер на всех концертах перед началом залезал в карманчик фрака, вытаскивал записку, читал и далее начинал дирижировать. Меломаны никак не могли понять и, наконец, с трудом выяснили у жены дирижера содержание записки: скрипки - слева, виолончели - справа. Видимо, многим нашим руководителям государственных органов неплохо бы знать, где находятся специалисты страны - металлурги, химики, корабелы, электронщики, энергетики, строители, геологи, машиностроители, экономисты.

\section{Белые ночи}

На конференциях же и съездах, проводимых академией МАНЭБ, удалось побывать не на многих.

Запомнилась 4 Международная конференция 1999 г. по экологии под эгидой МАНЭБ, Министерства науки и технологий РФ, РАН и др., которая проходила на борту теплохода «СанктПетербург». Маршрут следования Санкт-Петербург - Валаам - Петрозаводск. На корабле неплохо оборудованный конференц-зал, почти всегда на 100 \% заполненный участниками конференции. Делались перерывы на время посещения Валаама и других островов, Ладожского и Онежского озер и Петрозаводска. Красоты северо-запада, белые ночи, исторический Беломорско-Балтийский канал... У меня также был доклад по каталитической очистке технологических и выбросных газов.

Оргкомитет во главе с президентом МАНЭБ профессором Виктором Рогалевым рекомендовал докладчикам для предварительного ознакомления участников развесить на стендах свои доклады.

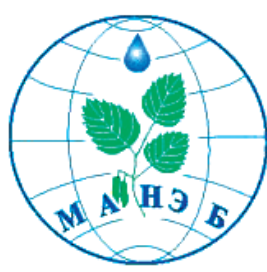

Мой большой доклад был неплохо оформлен и, как мне представлялось, снабжен рисунками и остроумными подзаголовками отдельных его частей. Доклад провисел в конференц-зале 1,5-2 дня и исчез. По судовому радио постоянно шло обращение оргкомитета с просьбой вернуть доклад. Во время обеда участник конференции, руководитель одного из департаментов Петербурга, сидевший за нашим столом, услышав очередное объявление о пропаже доклада, с серьезным лицом предложил мне не расстраиваться: «Ваш доклад пошел в дело. Вы видели, Евгений Зиновьевич, что во время причаливания к острову продавали шикарную селедку, которую заворачивали в Ваш доклад»? Шутка удалась. Доклад я сделал, но художественного текста так больше и не увидел. 


\section{Конкурсы «Инженер года»}

Хорошей формой привлечения инженерных кадров к научно-инновационной деятельности, выявления элиты инженерного корпуса, формирования интереса к инженерному труду молодежи явился конкурс «Инженер года», который проводит РосСНИО под руководством академика Юрия Гуляева и вице-президента РосСНИО Владимира Ситцева. Этот конкурс около десяти лет также проводится Тульским союзом научных и инженерных организаций по двум версиям: «Инженерное искусство молодых» (для участников до 30 лет) и «Профессиональные инженеры». Конкурс проводится по 10 номинациям: 1) «Горная промышленность и подземное строительство», 2) «Информатика, информационные сети, вычислительная техника», 3) «Машиностроение», 4) «Приборостроение», 5) «Радиотехника, электроника, связь», 6) «Строительство», 7) «Техника военного и специального назначения», 8) «Химия», 9) «Черная металлургия», 10) «Энергетика». Победителям выдается диплом лауреата конкурса и вручается красивый нагрудный знак «Инженер года», изготовленный на Монетном дворе. Награды ежегодно вручаются в Тульском областном Доме науки и техники в День российской науки 8 февраля. Торжественное награждение проводится руководством области, Думы, СНИО. Выпускается специальный номер газеты. Областной конкурс проводится под руководством президента СНИО профессора Александра Чукова и директора ДНИИТ Владимира Михайловского.

Активно участвуют в конкурсах инженеры Щекинского п/о «Азот», предприятий «Тулаточмаш», «Туламашзавод», Тульского оружейного завода, заводов г. Ефремова, научные сотрудники, профессора, доценты, инженеры Тульского госуниверситета, НИ РХТУ им. Д. И. Менделеева, «НИАП-Катализатор» и другие в самых различных номинациях. Наиболее активно в конкурсах участвуют инженеры оборонного завода «Сплав». Огромную поддержку и по организации областного конкурса, и по участию инженеров этого завода в конкурсе в течение многих лет оказывает генеральный директор (ныне

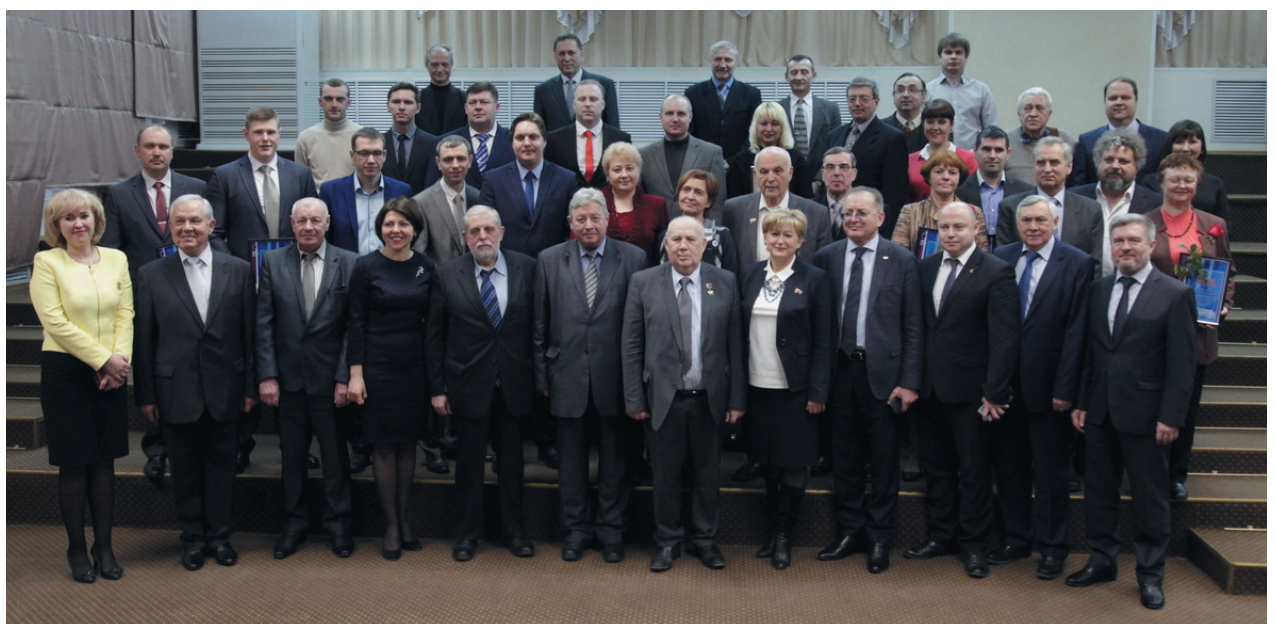

Победители организаторы конкурса «Инженер года» 
научный руководитель), Герой России, профессор Николай Макаровец.

Неоднократно и инженеры г. Новомосковска становились победителями конкурса, и в первую очередь в номинации «Химия» (технологические, производственные, научно-исследовательские работы), а также входили в состав победителей Всероссийского конкурса «Инженер года» (Е. Голосман, В. Ефремов, А. Дульнев и др.). Фамилии лауреатов Всероссийских конкурсов размещаются в зале Славы СНИО. Можно сожалеть, что по абсолютно необъяснимым причинам в столь престижном конкурсе не принимают участие ряд наших химических гигантов, и в том числе НАК «Азот», «Проктер энд Гембл», гипсовый комбинат. Неучастие в конкурсе связано с недопониманием руководителей предприятий и, безусловно, с недостаточной активностью инженеров этих предприятий.

И в феврале 2017 г. областной Союз научных и инженерных организаций отметил День российской науки. Полный актовый зал (руководители области, инженеры различных предприятий, студенты и преподаватели вузов). По номинации «Химия» шесть инженеров четырех организаций Новомосковска ( НИАП-Катализатор», НИ РХТУ им. Д. И. Менделеева, «Плазмотех» и «Полипласт») стали победителями конкурса. Всем им были вручены медали и дипломы.

\section{Красавец город}

Для участников съезда была подготовлена культурная программа. Это обзорные экскурсии по Екатеринбургу, посещение Ганиной Ямы (бывшего рудника, в районе которого были сброшены останки царской семьи и приближенных (сейчас там основан монастырь)) и экскурсия на границу Европы и Азии. Предлагалось посещение многочисленных музеев, выставок, театров.

Из-за плотного графика мне удалось лишь воспользоваться возможностью участвовать в короткой обзорной экс-

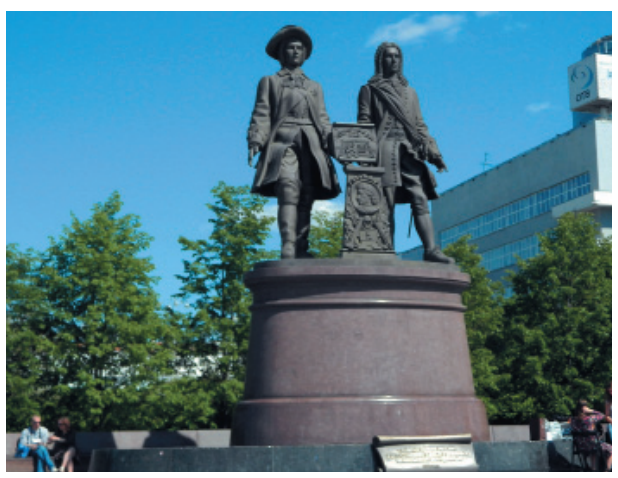

курсии по городу. Официально в столице Урала проживают 1,5 миллиона человек. Дороговизна земли заставляет строить много высотных зданий (второе место в России после Москвы). Построены и две самые большие высотки «Исеть» и «Высоцкий». Высота 54-этажной башни «Исеть» - 209 метров. Высота одного из самых энергоэффективных зданий в стране, 50-этажной башни «Высоцкий» - 188 метров. Имеются смотровая и даже вертолетная площадки. В здании находится и музей Владимира Семеновича Высоцкого. Эта высотка стала первым зданием в России, в котором стал проводиться вертикальный забег. Участники соревнований преодолевают пешком 1137 ступенек.

Одно из красивейших мест - это Плотинка (городской пруд) на месте бывшего главного казенного завода на небольшой реке Исеть. Рядом - красивейший памятник основателям города Василию Татищеву и Вилиму де Геннину. 
В городе много оригинальных памятников и сохранившихся старинных зданий.

Фактически большая часть осмотра города проходила через стекло автобуса. Выходили на Плотинке и у бывшего дома инженера Ипатьева - родного брата самого знаменитого химика технолога XX в. Владимира Николаевича Ипатьева (о гении науки академике В.Н. Ипатьеве я ранее опубликовал несколько статей).

\section{Ипатьевский дом}

Много лет назад, будучи в длительной командировке по городам Урала (Магнитогроск, Белорецк, Первоуральск и др.), где внедрял на металлургических и трубных заводах наши катализаторы для получения защитных атмосфер, я побывал и в Свердловске (ныне Екатеринбург). В городе работал и мой старший брат. В один из дней он ехал в Первоуральск и подвез меня на новотрубный завод, где эксплуатировался наш катализатор. По дороге подъехали к двухэтажному дому Ипатьева, в подвале которого была расстреляна царская семья. В доме в разные годы располагался Музей революции,

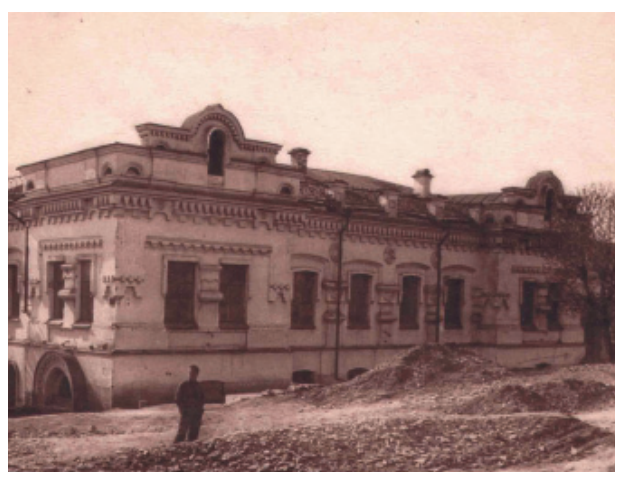

\section{Съезд решил}

На заключительном заседании было отмечено, что в докладах и материалах съезда нашли отражение современные направления развития химической науки и техники, многие актуальные разработки, намечены перспективы их развития и использования. Работа партийный архив, Антирелигиозный музей, выставки...

В сентябре 1977 г. дом был снесен. В 2003 г. на этом месте построен Храм-на-Крови. Высота храма - 60 м,

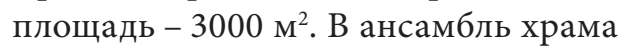
включен памятник царской семье. На стенах храма расположено огромное количество документов и фотографий. Это не только действующий собор, но и музейный комплекс. На осмотр собора было отведено 20-25 минут, так как надо было после экскурсии ехать на вечернее заседание съезда.

Жаль, конечно, что экскурсия была коротка, ибо посмотреть в городе можно очень многое. Но неумолимое время...

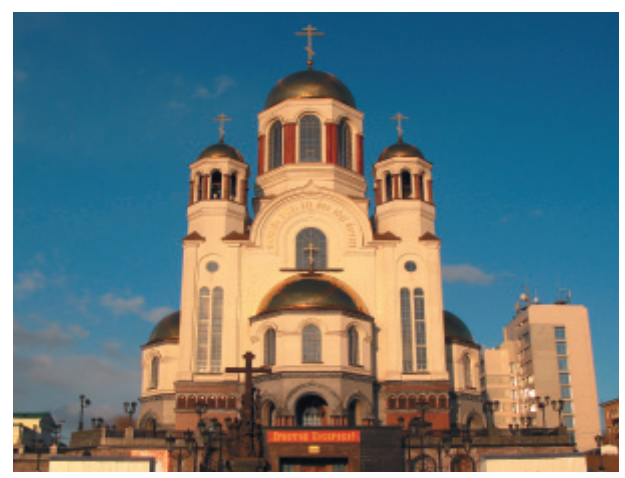

съезда еще раз подтвердила, что химия занимает особое положение в процессе перехода нашей страны к устойчивому развитию, позволяя решать широкий круг задач - от изучения молекулярных основ жизни и факторов устойчивости окружающей природной среды до со- 
здания новых материалов и источников энергии.

Съезд продемонстрировал достижения российской и мировой химической науки в таких областях, как инновационные разработки по созданию новых материалов и технологий, включая наноматериалы и нанотехнологии, создание новых лекарств, электрохимическая энергетика, альтернативные энергоносители и моторные топлива из растительного сырья, экологически безопасная (так называемая зеленая) химия и проблемы устойчивого развития. Особое внимание было уделено вопросам химического образования и просвещения, а также борьбы с хемофобией.

Съезд обращает внимание правительства страны и Комиссии по модернизации при Президенте РФ на недопустимость механического слияния университетов, академических институтов.

Съезд считает, что одним из важнейших социальных факторов успешной реализации провозглашаемой руководством РФ стратегии модернизации экономики России на основе инноваций является наличие высококвалифицированных научных и инженерно-технических кадров. Подготовка таких кадров требует усиления внимания общества к среднему и высшему техническому образованию, а также к школьному образованию, призванному вызвать интерес учащихся к изучению естест- венно-научных предметов - математики, химии, физики, биологии. В этой связи участники Менделеевского съезда считают необходимым просить Министерство образования и науки РФ обеспечить разработку и реализацию системы мероприятий по совершенствованию учебных программ (в том числе при увеличении количества часов на изучение химии и физики в школе) и методик преподавания химии и физики в средней школе.

Вместе с тем, несмотря на определенные успехи, съезд считает, что дальнейшее развитие химической науки и промышленности, химического образования и смежных отраслей, с учетом их значимости и потенциальных возможностей, требует принятия неотложных мер по ускорению коммерциализации результатов фундаментальных исследований и совершенствованию законодательной базы в вопросах интеллектуальной собственности. Необходимыми являются также обеспечение притока инвестиций, обновление технологий и инженерного обеспечения, расширение привлечения талантливой молодежи в химическую науку и промышленность, усиление ее социальной поддержки.

Кратко выскажу и свое мнение, которое излагал в ряде публикаций о работе отраслевых и академических институтов и вузов. Не способствовала успехам науки непродуманная реорганизация Академии наук, странное объединение

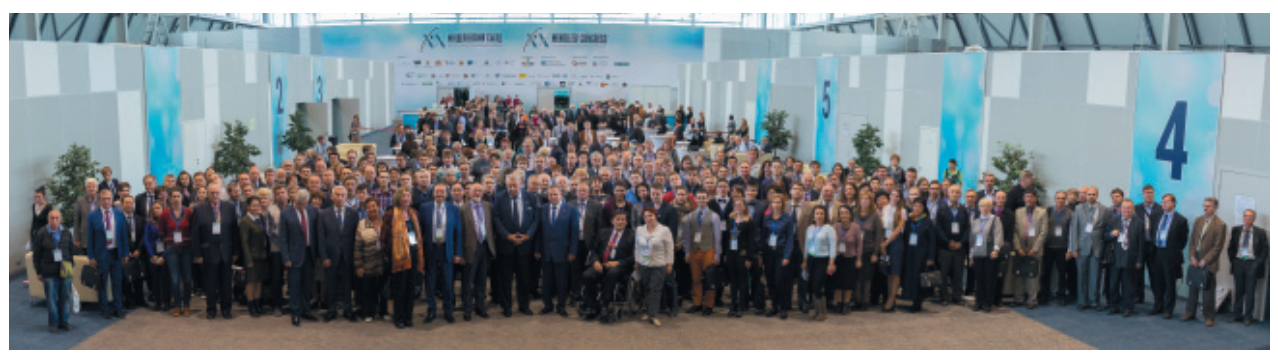


вузов, сокращение сотрудников, низкое финансирование, превращение образования в школах и институтах в услуги. Напомню всем высказывание, приписываемое канцлеру Бисмарку: «Войну выигрывает школьный учитель». По соотношению затрат на науку и ВВП Россия на последнем месте среди крупнейших развитых стран. Взаимоотношение власть предержащих и научного сообщества все более напоминает «я проверялся, Вы больны не мною».

Гибельным для российской науки является нижайший престиж ученых в последние годы. В Канаде проводился опрос: «Какое достижение больше поднимает патриотический дух - Нобелевская премия или число медалей на Олимпийских играх»? Почти 75 \% канадцев выбрали Нобелевскую премию. У нас же, как писала газета «Известия», олимпийский Сочи важнее Стокгольма.

Исчезновение с карты России из 6000 более 5000 отраслевых НИИ и КБ во многом сократило и возможности по внедрению разработок академических НИИ и вузов в промышленность. Задавал не один раз вопрос: сколько в России инженеров? Похоже, точных данных нет. На І съезде инженеров России в Кремле в 2003 г. два докладчика назвали различные цифры - 15 и 11 миллионов. В Интернете точная цифра также отсутствует. Более конкретные сведения о количестве выпускаемых нашими вузами инженеров - более 400 000. Огромная армия выпускников, но далеко не все работают по специальности. Приятно, конечно, как мантру, повторять «мир меняют инженеры и ученые». А почему ИНЖЕНЕРЫ уходят в другие сферы? Не престижно, как и наука. Зарплата инженеров в России в 2016 г. в регионах в различных отраслях колеблется от 11 000-15000 до 100000 руб. и более. To, что наши, например нефтяники, работающие в тяжелейших условиях, получают высокие зарплаты, нет никаких сомнений. Но почему инженеры, выполняющие примерно одну и ту же работу в мегаполисах, и прежде всего в Москве, получают в 3-5 раз более высокую зарплату, чем в регионах, например в Новомосковске? Можно, конечно, приказом раздвинуть Москву не только до Калужской области. А что далее?

Налоги тысяч российских предприятий остаются в Москве, ибо предприятия эти зарегистрированы в столице (хотя работают в регионах). В том числе и поэтому добытчики нефти, газа, химики, металлурги и т. д., хотя работают в тяжелейших условиях и отравляются вредными выбросами, получают куда меньшую зарплату, чем москвичи. Да и сами города, где стоят эти предприятия, едва выживают.

Напомню рекламу, где девочка пьет стакан за стаканом сок и на замечание папы: «Деточка, ты же лопнешь!» - отвечает: «А ты, папа, отойди».

Неужели кому-то еще непонятно, что нужны другие законы, по которым та часть налогов, которая не идет в федеральный центр, должна оставаться там, где находятся предприятия?

Как в очередной раз не вспомнить мудрецов: «Если не знаешь куда плыть, никакой попутный ветер не поможет».

\section{Российское химическое общество}

В рамках съезда несколько часов одного из вечерних заседаний было

отведено VIII отчетно-выборному съе- 
зду Российского химического общества им. Д. И. Менделеева (РХО).

І съезд РХО состоялся в 1991 г. в Ростове после распада СССР. Я был одним из делегатов съезда. Был принят Устав и президентом Российского химического общества стал академик Ю.А. Золотов. В последующие годы президентом общества избирались академики А. И. Русанов, П. Д. Саркисов, А. Ю. Цивадзе.

В работе VIII съезда приняло участие 90 делегатов из 125 избранных в региональных организациях, и в том числе от Тульской организации химического общества автор этих строк.

Среди участников - 22 академика и члена-корреспондента РАН, 30 профессоров, 28 научных сотрудников и инженеров.

С докладом о работе общества выступил президент РХО им. Д. И. Менделеева академик А. Ю. Цивадзе. Отметил сложное положение практически всех общественных организаций, отсутствие помощи руководства регионов, министерств, отсутствие помещений, плохое финансирование. Об этом же резко Аслан Юсупович говорил и при открытии ХХ съезда в присутствии двух тысяч участников съезда, представителя президента России Уральского федерального округа (округ по площади превышает площадь территорий Германии, Франции, Великобритании, Испании вместе взятых), руководителей РАН, ФАНО, губернатора Свердловской области и других.

После распада Советского Союза PХО им. Д. И. Менделеева существует на весьма скромный бюджет из минимальных членских взносов. Причина - статус общественной организации, отсутствие финансирования от предприятий, вузов, НИИ...
В зарубежных химических обществах ситуация иная. Например, в Великобритании химическое общество - это профессиональная структура, в которой состоит около 55000 членов. У общества большой бюджет, позволяющий выделять средства на премии, стипендии, издание журналов.

Необходимо срочно оздоровлять деятельность Российского химического общества.

А. Ю. Цивадзе были внесены и далее утверждены делегатами предложения по изменению устава, касающиеся дифференцированного членства с соответствующими различными вступительными и ежегодными членскими взносами. Важным явилось изменение устава в части, что членами общества наряду с общественными организациями могут быть также юридические лица. Было поручено президиуму общества сформулировать предложения о попечительском совете. Тем более что исключительно полезный опыт попечительских советов известен на примере Географического общества, Военно-исторического. Решено учредить золотую медаль РХО им. Д. И. Менделеева, которая будет присуждаться за выдающиеся заслуги в области химических наук и техники. Медали будут присуждаться ежегодно российскому и иностранному ученым, представителю отечественной промышленности.

Конечно, далеко не все благостно в деятельности общества. Крайне мало молодых членов общества, и, на мой взгляд, большой потерей в работе общества является длительная приостановка (главным образом из-за финансовых проблем) издания популярного бюллетеня «Химия в России». 
Да, без хорошего финансирования практически невозможно проведение конференций, конкурсов и т. д. Еще раз отмечу, что эти вопросы реально могут быть решены только с привлечением коллективных членов, которые смогут оказать спонсорскую помощь НТО. Но все же полагаю, что многие проблемы химического общества, НТО горняков, металлургов, машиностроителей и др. связаны с крайне плохой информированностью инженеров, научных сотрудников, особенно молодых, о задачах обществ, о престижности участия в работе этих организаций. Практически не знаю выступлений по телевидению, радио, публикаций в центральной и региональной прессе руководителей НТО, членов президиумов с множеством высоких научных регалий.

Давно размышляю о трудностях общественной работы. Многие организации стали частными, и далеко не везде там, да и в государственных, руководство понимает необходимость участия в работе Российской инженерной академии (РИА), Международной академии экологии (МАНЭБ), Союза научных и инженерных общественных объединений (СНИО), Менделеевского химического общества и других.

А коли такие проблемы, да и других достаточно, то в первую очередь молодые сотрудники, инженеры не рвутся к участию в общественной жизни. Всем известно, что часть мероприятий осуществляется в рабочее время, и приходится брать свои отпускные дни.

\section{В гости к Дмитрию Ивановичу}

В Санкт-Петербурге располагается около 200 музеев, и все же позволю дать совет будущим участникам юбилейного съезда и, безусловно, всем, кто посетит
А с учетом скромных зарплат, особенно молодых, да их излишнего прагматизма результат известен. Очень вероятен исход остаться всем нам без молодого резерва.

Президентом общества вновь был избран директор Института физической химии и электрохимии РАН, академиксекретарь отделения химии и наук о материалах РАН А. Ю. Цивадзе, а ученым секретарем - кандидат биологических наук Н. Р. Косинова. Были избраны вице-президенты, президиум РХО и члены правления. От Тульской области членами правления избраны председатель областного правления Тульского химического общества профессор Тульского университета В.М. Панарин и переизбран заместитель председателя областного правления (с 1967 г.), главный научный сотрудник «НИАПКатализатор» профессор Е.3. Голосман, являющийся членом центрального правления с 1994 г.

Приятным и многообещающим заключением съезда явилось сообщение, что следующий Менделеевский съезд будет посвящен 150-летию открытия периодического закона и 150-летию образования Русского химического общества (ранее называлось Русское физико-химическое общество).

Естественно, что по праву съезд пройдет в городе Санкт-Петербурге, в котором все знаменательные вышеуказанные события и произошли.

Сие событие произойдет в 2019 году.

Санкт-Петербург до знаменательного форума, - посетить музей Дмитрия Ивановича Менделеева. Музей находится в историческом здании Двенадцати кол- 
легий Санкт-Петербургского государственного университета на Васильевском острове. Музей был основан в 1911 г. по инициативе участников II Менделеевского съезда и находится в бывшей казенной квартире Дмитрия Ивановича, где он прожил почти четверть века, будучи профессором и заведующим кафедрой университета.

По приглашению Д. И. Менделеева студенты могли прийти на консультации, не выходя из здания университета,

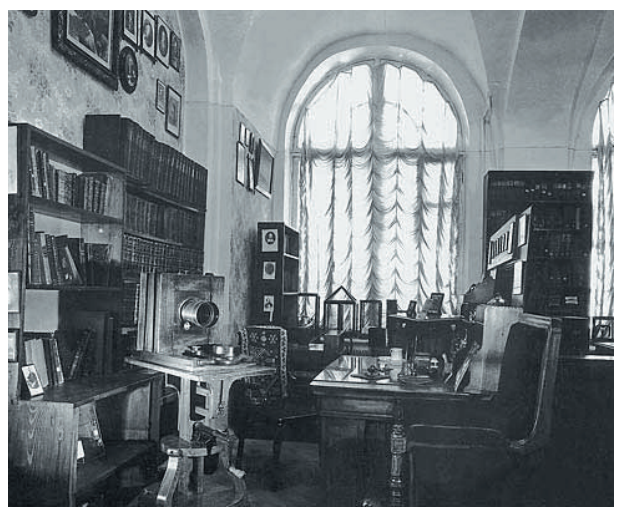

Кабинет Менделеева

в Санкт-Петербургском университете

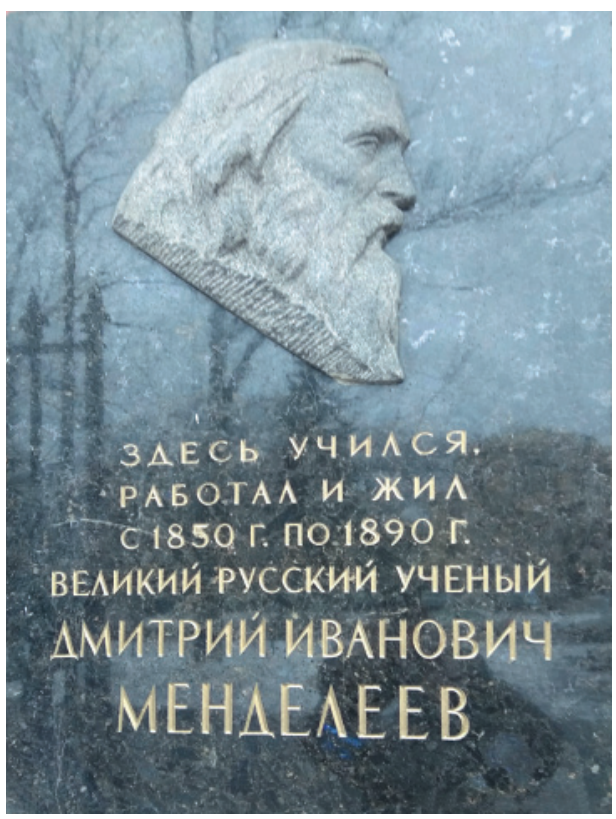

через дверь, ведущую в квартиру профессора. Сохранился кабинет ученого, архив и собранная им огромная библиотека, многие из книг которой были вручены ему коллегами и друзьями.

В этой квартире устраивались научные и художественные «среды», на которых бывали скульптор Петр Клодт; художники Иван Крамской, Архип Куинджи, Илья Репин, Иван Шишкин; музыкальный критик, историк искусств Владимир Стасов; композитор Александр Бородин; физиолог Иван Сеченов; адмирал Степан Макаров; поэт Александр Блок (зять Менделеева). Музей располагает прекрасной коллекцией картин, которые собирал Д. И. Менделеев. Сохранились конторка, за которой Менделеев изобретал свой периодический закон, над которым работал 25 лет; его старинный фотоаппарат; шахматы; огромная библиотека; крупное собрание документов, отражающих жизнь и научную деятельность ученого; макет ледокола, изобретенного Менделеевым; приборы, на которых он проводил исследования; карта с отмеченными городами, где побывал Менделеев и скатерть с автографами знаменитых, известных людей того времени. Музей ежегодно посещают тысячи людей, среди которых были нобелевские лауреаты И. Пригожин, Г. Сиборг, Л. Полинг, П. Капица, президент Франции Жак Ширак, знаменитые российские и зарубежные ученые.

Полагаю, что ни один химик, физик, металлург, медик, метролог, нефтяник, полярник, угольщик, экономист, метеоролог, школьный учитель, преподаватель вуза, научный сотрудник, художник, композитор, скульптор, воздухоплаватель, школьник, студент не может не зайти в музей энциклопедиста, гения науки. 
Съезд обратился к президенту РАН и в Министерство иностранных дел России, международные организации с просьбой объявить 2019 г. «Международным годом Периодической таблицы химических элементов».
И все же вслед за Ираклием Андрониковым хочется повторить: «Давайте поднимем уровень наших дискуссий до уровня кулуарных разговоров».

А пока пожелаем удачи будущим участникам мирового события.

\section{Эпилог}

Любимый пример из истории. Наполеон проигрывал компанию в Египте. Военный лагерь был окружен и простреливался противником. Наполеон приказал собрать в самое безопасное место лагеря ослов и ученых, считая, что в первую очередь надо спасать транспорт и науку.

\section{Cite this article as (как цитировать эту статью):}

Holosman E.Z. Engineering and scientific elite at the Mendeleev congress in Ekaterinburg and reflections about science and education. Chimica Techno Acta. 2017;4(1):54-99. 